\title{
ESTUDIOS
}

\section{La música entre escritura y oralidad: la guitarra barroca, el guitarrón chileno y el canto a lo divino ${ }^{1}$}

\author{
Music between Written and Oral Traditions: the Baroque \\ Guitar, the Chilean Guitarrón and the Canto a lo Divino
}

\author{
por \\ Alejandro Vera \\ Instituto de Música \\ Pontificia Universidad Católica de Chile, Chile \\ averamus@gmail.com
}

El presente artículo consta de dos partes. En la primera se documenta la importancia que tuvo la guitarra barroca (o de cinco órdenes) en el Chile colonial, prestando una atención especial a Santiago pero incorporando, también, referencias novedosas acerca de otras ciudades y pueblos. Esta sección se apoya en una revisión sistemática efectuada por el autor durante varios años en diversos archivos y colecciones (como el fondo Escribanos de Santiago del Archivo Nacional Histórico), que le ha permitido localizar un número muy significativo de guitarras o instrumentos afines para los siglos XVI a XVIII.

En la segunda parte se plantea una nueva hipótesis acerca del origen del guitarrón chileno y el canto a lo divino, vinculando estas manifestaciones tradicionales con la práctica colonial de acompañar la música sacra con la guitarra y entonar salmódicamente los textos litúrgicos. Para ello se conjugan la evidencia documental proporcionada en la primera sección, otros datos inéditos respecto de las prácticas músico-litúrgicas del Chile colonial y la información etnográfica contenida en estudios previos de diversos autores.

De esta forma se intenta vincular de manera convincente una música del pasado, de tradición predominantemente escrita como la de la Colonia, con una música actual, de tradición predominantemente oral como el canto a lo divino.

Palabras clave: música en Chile colonial, guitarra barroca, canto a lo divino, guitarrón chileno, música de tradición oral, música de tradición escrita.

This article is divided into two parts. In the first part the importance of the baroque guitar of five courses in colonial Chile is documented mainly in Santiago (the capital) but also in other cities and villages of the country. The data was gathered by the author after several years of systematic work in different archives and collections such as the

1 Este trabajo es resultado del proyecto Fondecyt 1120233, titulado "La guitarra entre dos mundos: procesos de producción, transmisión y recepción de la música para guitarra de cinco órdenes entre España e Hispanoamérica, durante el siglo XVIII". Una versión preliminar del mismo fue presentada como conferencia en el VIII Congreso Chileno de Musicología, en la Universidad Austral de Chile, Valdivia, 15 de enero de 2015. Agradezco a don Manuel Dannemann y David Andrés Fernández su lectura y observaciones, así como a don Luis Merino sus valiosas sugerencias durante el proceso de edición del texto. 
Escribanos de Santiago collection at the National Historical Archive. As a result a significant number of guitars and related instruments from the sixteenth to the eighteenth century were identified.

The second part presents a new hypothesis about the origin of the Chilean "guitarrón" and the traditional vocal practice known as "canto a lo divino". Both probably stemmed from the colonial practice of accompanying sacred music with the guitar while using psalm intonation formulae to sing the liturgical texts. This hypothesis is supported by the data presented in the first part combined with previously unknown data about music and liturgical practices in colonial Chile along with ethnographic data published previously by other scholars. The final purpose is to establish convincing links between the colonial music mainly of written tradition and the present practice of the "canto a lo divino" which belongs mainly to the oral tradition.

Keywords: music in colonial Chile, baroque guitar, canto a lo divino, Chilean guitarrón, music of oral tradition, music of written tradition.

\section{INTRODUCCIÓN}

"Los antiguos autores españoles, Victoria, Cabezón, etc., componían una música que a mi juicio representa más propiamente el alma española, llena de grandeza y noble dignidad, que la música que se ha desarrollado posteriormente, que solo se refiere a un aspecto inferior: al garbo y chulerías, con todos los giros árabe-andaluces, sus eternas jotas y guitarras, todo ese aparato colorista y falso que descorazona".

El párrafo anterior, escrito por el compositor chileno Alfonso Leng en $1927,{ }^{2}$ resulta apropiado para iniciar un artículo como este, que explora la relación entre el pasado y el presente en el campo de la música; esto porque Leng reproduce prejuicios acerca de la guitarra y la cultura popular que, como veremos, se habían gestado varios siglos antes. Desde luego, la premisa de que la historia de la música involucra el pasado y el presente no representa una novedad, pues ha sido defendida por diversos autores desde un punto de vista conceptual o filosófico. Jim Samson, por ejemplo, ha afirmado que la historia del arte en general (y la música en particular) tiene un carácter más presentista que la historia política y social, por cuanto las "obras" no son solo objetos del pasado, sino que "están vivas" en el presente. ${ }^{3}$ Sin embargo, en las páginas que siguen dicho planteamiento se lleva a un plano más específico, en el que el pasado está representado por el extendido uso de la guitarra barroca (o de cinco órdenes) en el Chile colonial, y el presente por la práctica actual del guitarrón y el canto a lo divino.

De esto último se desprende otro de los aspectos que interesan a este trabajo: la vinculación entre la música de tradición escrita y la de tradición oral. Tampoco se trata de un tema nuevo en el campo musicológico, como lo demuestran, entre otros, el artículo de Antonio Corona concerniente a las relaciones entre la música del siglo XVII y la música tradicional de Veracruz (México) ${ }^{4}$ o, en el caso chileno, las investigaciones de Víctor Rondón respecto de los posibles vínculos entre la música de tradición oral y las antiguas misiones jesuitas. ${ }^{5}$ Sin embargo, en este trabajo

2 Leng 1927. Citado por Uribe Valladares 2004: 32. Las cursivas son mías.

3 Samson 2009: 8-9.

4 Corona 1995.

5 Esta relación es abordada en diversas partes de su tesis doctoral, particularmente en el capítulo 5 . Ver Rondón 2009. 
se espera no solo proponer analogías entre la música colonial y la de tradición oral, sino también hipótesis de los procesos históricos que pudieran explicarlas.

Considerando lo anterior, he dividido el texto en dos partes. En la primera abordo la importancia que tuvo la guitarra en el Chile colonial, prestando una atención especial a la ciudad de Santiago, pero incorporando referencias novedosas respecto de otras ciudades y pueblos. Aparte de la bibliografía disponible, esta sección se basa en una revisión sistemática efectuada durante varios años en el fondo Escribanos de Santiago del Archivo Nacional Histórico, que ha permitido inventariar más de doscientos instrumentos en manos de particulares, unos setenta de ellos vinculados con la guitarra. Como es sabido, este fondo documental incluye testamentos, inventarios y otros documentos afines que permiten identificar los bienes que se hallaban en manos de los habitantes de la ciudad, por lo que constituye un repositorio ideal para conocer la vida privada del período. Dicho fondo será complementado con otros tipos de documentos, conservados fundamentalmente en archivos conventuales (disposiciones, actas, libros de cuentas, etc.). Más allá de los datos específicos, que me parecen relevantes, me interesa mostrar cómo las connotaciones sociales y funciones asociadas al instrumento fueron cambiando a lo largo de los siglos XVII y XVIII.

En la segunda parte aprovecharé la información proporcionada en la primera para formular una nueva hipótesis acerca del origen del guitarrón chileno y la práctica del canto a lo divino. Más que aportar nuevos datos de estos últimos, me interesa establecer vínculos convincentes entre lo que actualmente se sabe de ellos y la música del período colonial. Esto explica que no haya realizado trabajo de campo, a excepción de una entrevista que sostuve con el cantor y profesor Francisco Astorga, que será citada más adelante. Sin embargo, he intentado aprovechar al máximo el trabajo de campo que otros colegas han realizado, prestando atención tanto a sus propios juicios o afirmaciones como a los testimonios que recogen de los guitarroneros y cantores.

Finalmente, en las conclusiones presentaré, entre otras ideas, una breve reflexión acerca de la pertinencia de retornar al problema del origen en la musicología actual, a pesar de los cuestionamientos fundados que le han dedicado en las últimas décadas diversos especialistas.

\section{LA GUITARRA EN EL CHILE COLONIAL ${ }^{6}$}

La musicología, y en particular la musicología histórica, es en gran medida historia de la cultura material, aunque rara vez se muestre consciente de ello. Al estudiar normalmente partituras, instrumentos y otros objetos materiales, el musicólogo examina no tanto estos objetos en sí mismos, sino "sus usos, sus apropiaciones

${ }^{6}$ Además de lo indicado en la nota 1, presenté como ponencia una primera versión de este apartado en las IX Jornadas de Historia Colonial, bajo el título "Los instrumentos musicales como espejos de la sociedad colonial: la guitarra en Santiago de Chile (siglos XVII y XVIII)", en el Centro Patrimonial Recoleta Dominica, Santiago (Chile), 27 de mayo de 2014. 
sociales, las técnicas involucradas en su manipulación, su importancia económica y su necesidad social y cultural". ${ }^{7}$ Por medio de su estudio pretende entonces conocer ciertas prácticas musicales y su interacción con un contexto sociocultural determinado. En esta primera parte, el objeto en cuestión es la guitarra y, más específicamente, la guitarra de cinco órdenes, también conocida en la actualidad como "guitarra barroca" (ver figura 1); el contexto es la ciudad de Santiago y otras localidades del Chile central en los siglos XVII y XVIII, y la hipótesis es que el estudio de dicho instrumento puede permitirnos mapear una parte de los cambios que experimentaron la propia sociedad y sus habitantes durante este período.

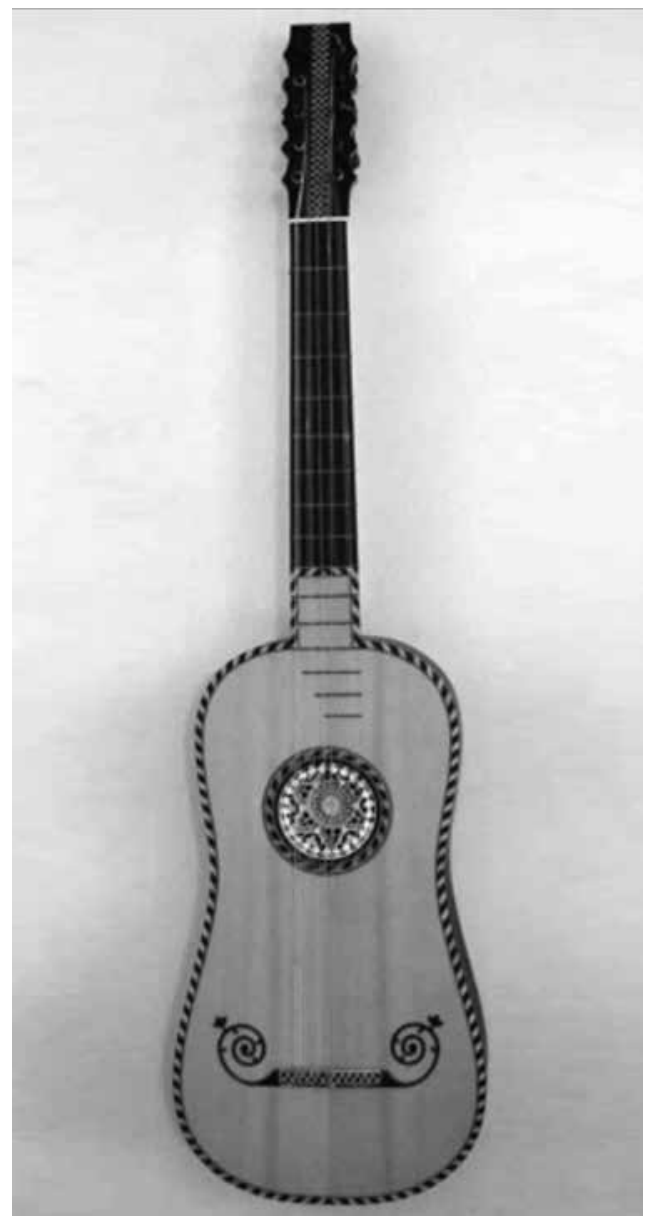

Figura 1. Guitarra barroca.

7 Barros 2008: 32. 
La elección de la guitarra se sustenta en varias razones: primero, fue uno de los pocos instrumentos musicales, si no el único, que tuvo plena vigencia durante toda la Colonia; segundo, estuvo presente en las distintas capas de la sociedad y tanto en el ámbito urbano como rural; tercero, participó en los contextos músicorituales más diversos, como la liturgia católica, el teatro, la vida privada y las fiestas públicas que tenían lugar anualmente; y cuarto, según veremos en la segunda parte, su uso se ha extendido hasta nuestros días con la misma diversidad señalada.

Otro aspecto importante que se debe considerar es que la guitarra encarnó, desde sus inicios, las tensiones sociales de su tiempo. Los principales testimonios al respecto proceden de España. Quizás el primero y más conocido es el de Covarrubias y Orozco en su diccionario de 1611, en el que califica a la guitarra como "un cencerro, tan fácil de tañer, especialmente en lo rasgado, que no hay mozo de caballos que no sea músico de guitarra". A la vihuela, en cambio, la describe como un instrumento "hasta nuestros tiempos muy estimado" en el que ha habido "excelentísimos músicos" y considera su caída en desuso como "una gran pérdida, porque en ella se ponía todo género de música puntada...". ${ }^{8}$ En términos similares se expresa el teórico Pietro Cerone en su tratado de 16139:

“QQuién duda que hoy día los que no saben cantar más que unas tonadas en la quitarra destemplada, y todos los que no saben tañer otra cosa más que las vacas y la zarabanda, quieren ser llamados Músicos?”.

Mientras el juicio era extremadamente negativo a comienzos del siglo XVII, a fines del mismo la situación había cambiado un tanto. Esto queda de manifiesto en la opinión de Gaspar Sanz, en su conocida Instrucción de música de 167410:

"Otros han tratado de la perfección de este instrumento, diciendo algunos, que la guitarra es instrumento perfecto, otros que no; yo doy por un medio, y digo que ni es perfecta ni imperfecta, sino como tú la hicieres, pues la falta o perfección está en quien la tañe, y no en ella”.

Otro importante guitarrista, Santiago de Murcia, confirma en el prólogo de un manuscrito suyo -producido en España pero conservado en Chile- que el juicio de Sanz se mantenía vigente a comienzos del siglo XVIII, al advertir al lector contra "aquellos congregados en el número de aporriantes, o variadores de bellota, que pretenden saborar el sentido del oído a fuerza de andar a puñadas con la guitarra"." Además, nos muestra que el estilo "rasgueado", tratado tan duramente por Covarrubias y Cerone un siglo antes, era ahora perfectamente

8 Covarrubias Orozco 1979: 1008. Este texto ha sido citado, entre muchos otros, por Robledo 1989: 56.

9 Cerone 1613: 65.

10 Sanz 1966: LXI.

11 Murcia 2010: 5. 
aceptado si se ejecutaba de modo delicado y con "primor". ${ }^{12}$ Una opinión similar deja entrever Fernando Ferandiere en su Arte de tocar la guitarra... de 1799, cuando afirma que este es

"un instrumento nacional tan completo y hermoso, que todas las naciones lo celebran, aun sin saber hasta dónde llegan las fuerzas de nuestra guitarra, porque los unos se contentan con rasguear el fandango y la jota, los otros con acompañarse unas boleras; los músicos con acompañarse arias, tonadillas, etc". ${ }^{13}$

Este cambio de énfasis del instrumento en sí al modo de ejecutarlo (es decir, del objeto a la performance) permitió su aceptación por parte de la cultura oficial desde fines del siglo XVII. Al mismo tiempo, queda claro que estas discusiones trascendían al objeto en sí para abarcar modos de ser y estar en la sociedad del antiguo régimen.

¿Se manifestaron estas tensiones sociales en torno a la guitarra en el Chile colonial? A pesar de la ausencia de testimonios tan detallados como los de Sanz, Murcia o Ferandiere, los datos encontrados en distintas fuentes sugieren que la respuesta es afirmativa. Los indicios más antiguos que he podido localizar provienen de los conventos. Las "constituciones municipales...” franciscanas de Santiago, redactadas en 1680 , ordenan que

“para quitar abusos, y escándalos, que los prelados conventuales, y mucho más el R. Padre Provincial averigüe si hay en algún convento quien tenga, o toque guitarras, y con mayor cuidado se averigüe, y penitencie a quien las tocare en casa de seglares; pues el ministerio de religioso seráfico es exhortar a la penitencia. Y así se manda a mayor observancia que ningún religioso toque instrumento alguno, así en las fiestas de nuestros conventos, como en las de los ajenos". ${ }^{14}$

De este primer testimonio podría deducirse que el instrumento no era tolerado en las casas conventuales, al menos en las de los franciscanos. Sin embargo, los nuevos "Estatutos municipales" de 1689 nos muestran lo apresurado de este juicio. En ellos se reitera la prohibición de tener o tocar "guitarras dentro, o fuera de casa", pero se añade que "si conviniere se podrá permitir [hacerlo] al vicario de coro, dentro de casa solamente". ${ }^{15}$

12 "Tocante a la mano derecha, en primer lugar se advierte que el común estilo a todos los principiantes es que pongan el dedo meñique fuera de la puente de la guitarra, para que esté más firme la mano, porque muchos no pueden entonces herir las cuerdas puesta la mano en el aire, sino de la suerte dicha; lo cual no se verá practicado en ningún diestro, que trate a este instrumento con algún primor, mayormente cuando son obras delicadas y en ellas hay golpes rasgueados, pues debe en estos casos tocarse en el medio del instrumento, y solo usar de la mano puesta en la puentecilla cuando se necesita que suene más, como cuando se acompaña a otro instrumento". Murcia 2010: 8.

13 Citado por Vicent 2002: 149.

14 Archivo Franciscano de Santiago, Actas del definitorio, vol. 1, fol. 53. También citado parcialmente en Millar y Duhart 2005: 150. La prohibición se reitera en la nueva versión de las constituciones elaborada en 1683. Ver Archivo Franciscano de Santiago, Actas del definitorio, vol. 1, fol. $88 \mathrm{v}$.

15 Archivo Franciscano de Santiago, Actas del definitorio, vol. 1, fol. 142v. 
A primera vista, podría parecer que los franciscanos se habían vuelto más tolerantes hacia el instrumento en los nueve años transcurridos entre ambos documentos; pero pienso que existe otra explicación más convincente. Si volvemos a las citadas constituciones de 1680, la guitarra no es lo único que se prohíbe. Ocurre lo mismo con las comedias conventuales, "los cohetes y otras demostraciones profanas" en las "fiestas de la O" ${ }^{16}$ Por tanto, lo que se proscribe no es el instrumento en sí, sino algunas prácticas que de una u otra forma se vinculan con él. Prueba de ello es que en 1689 se autoriza al vicario de coro a tocar la guitarra, porque, al tratarse del máximo responsable de la música conventual, se espera que el modo en que la ejecute se ajuste al comportamiento esperado en un fraile de la orden. Esta visión coincide con la expresada por Sanz y Murcia en la misma época, lo que sugiere que el paso de un énfasis en el objeto a un énfasis en la performance se dio también en el Chile colonial.

Los documentos del convento de La Merced de Santiago confirman que el empleo de la guitarra por parte de frailes no era excepcional en esos años. De 1676 a 1687 el inventario señala la presencia de "una buena guitarra", junto a otros instrumentos (un órgano pequeño, dos cornetas, un fagote, una dulzaina, un arpa, un bajón y dos vihuelas), además de partituras. Todo ello estaba a cargo del vicario de coro. ${ }^{17}$

El panorama es distinto en el siglo XVIII, pues en la documentación de los conventos santiaguinos que he revisado (agustino, franciscano, mercedario y clarisas de la Victoria) no se menciona ya guitarra alguna. Sí aparece, en cambio, en los conventos de otras ciudades. En 1726 hallamos "una guitarra nueva con que se tañe en las misas" en el convento agustino de La Serena; ${ }^{18}$ y en 1729 figuran un arpa y una guitarra en el beaterio de trinitarias de Concepción. ${ }^{19}$

Un poco más tarde encontramos guitarras en las iglesias rurales. En la hacienda de Huaquén, cercana a Santiago y dependiente de la orden mercedaria, figura "Una guitarra que sirve para tocar en la Iglesia" entre 1737 y $1747 ; 20$ y en la misión jesuita de San Cristóbal, cercana a Concepción, hallamos en la misma época una guitarra y un violín. ${ }^{21}$

Parece pues que, en el siglo XVIII, nuestro instrumento fue empleado con menor frecuencia en las iglesias capitalinas, pero no así en las de otras ciudades y las zonas rurales. Sin embargo, su presencia en estas últimas se vería también en

16 Archivo Franciscano de Santiago, Actas del definitorio, vol. 1, fol. 52v.

17 Archivo Mercedario de Santiago, Libro 1 de Provincia, fols. 6, 31v y 52. Además, en 1678 el provincial de la orden, fray Manuel de Toro Mazote, regaló al convento otra arpa. Más información acerca de la vida musical de dicho convento se encuentra en Vera 2004a y Vera 2004b.

18 Archivo Agustino de Santiago, Libro de documentos de La Serena (1595-1794), fol. 212 [o 12 v, según la foliación alternativa].

19 Archivo General de Indias, Chile, vol. 153 (información relativa al beaterio de Concepción), fol. 35. Cf. con Muñoz Olave 1926: 69.

20 Archivo Mercedario de Santiago, Libro de administración de la Hacienda del Huaquén (17061750 ), fols. 19-29.

21 Archivo Nacional Histórico, Jesuitas de Chile, vol. 24, "Memoria de las alhajas y ornamentos que tiene la Iglesia de la misión de San Cristóbal”, fol. 304. El documento no lleva fecha, pero los años circundantes en el tomo lo sitúan en las décadas del 40 y 50 de dicho siglo. 
entredicho, ya que entre 1799 y 1803, en el convento franciscano de Santa Rosa de Curimón, se compró "un órgano que costó doscientos veinte y dos pesos para quitar la indecencia de la guitarrita, que se tocaba en las misas".22

El aparente confinamiento de la guitarra a la periferia de las instituciones religiosas podría ser de especial relevancia y volveré a referirme a ello en la segunda parte de este trabajo. Pero antes resulta interesante ver qué ocurría con el instrumento en el ámbito privado. Una revisión del fondo Escribanos de Santiago ha arrojado 69 guitarras o instrumentos afines entre 1587 y $1805 .{ }^{23}$ Más precisamente, encontramos 44 guitarras, 9 “discantes" y 13 vihuelas, además de una cítara, ${ }^{24}$ una bandola ${ }^{25}$ y una bandurria ${ }^{26}$ que aparecen de forma excepcional, por lo que nos las consideraré para el análisis (ver el detalle en la Tabla 1).

Debido a esta variedad, resulta necesario considerar qué se entendía entonces por guitarra, discante y vihuela. Covarrubias define guitarra en 1611 como un instrumento que "no tiene más que cinco cuerdas, y algunas son de solas las

22 Archivo Franciscano de Santiago, "Libro de disposición del convento de Santa Rosa Viterbo en el valle de Curimón", sin foliar, "Adelantamientos" para el período que va del 25 de abril de 1799 al 25 de noviembre de 1803. Agradezco este dato a María José Castillo.

23 Además de la revisión que yo mismo he efectuado en el archivo, he contado con la colaboración, en diversos proyectos relacionados con el Santiago colonial, de Constanza Alruiz, Jaime Canto, Laura Fahrenkrog, Daniela Maltrain y Lía Rojic como ayudantes de investigación.

24 Según el diccionario de Covarrubias (1611), la cítara era una "vihuela de arco con muchas cuerdas...", conocida también como "Lira". El diccionario inédito de Francisco del Rosal (1611) y el diccionario de la Real Academia Española (en adelante RAE) en sus ediciones de 1729 y 1780 informan que "cítara" era lo mismo que "cítola" (el documento citado indica "sítora", una variante que mezcla ambos términos). A diferencia de Covarrubias, el diccionario de español-inglés de John Stevens (1706) traduce cítara como "lute", lo que marca un cambio en la concepción del instrumento a uno de cuerdas pulsadas. Este cambio se ve confirmado por la definición de 1729 del diccionario de la RAE: "Cithara [sic]: Instrumento músico, semejante algo a la guitarra, pero más pequeño y redondo. Tiene las cuerdas de alambre, y se tocan con una pluma cortada, como para escribir de gordo". Ya que el documento que menciona la cítara es de 1642, es posible que se acerque más a la descripción de Covarrubias. De no indicarse lo contrario, he consultado los diccionarios históricos citados en la versión digital preparada por la RAE y disponible en http://ntlle.rae.es/ntlle/SrvltGUILoginNtlle (consultado el 11 de diciembre de 2014).

25 Según el citado Diccionario de la RAE, en sus ediciones de 1726 a 1803 , era un instrumento musical de cuatro cuerdas con cuerpo similar al del laúd.

26 Covarrubias no incluye el término en su diccionario. Sí lo hace Rosal (1611), aunque solo para decir que es un "instrumento de Música pastoril”. El diccionario de español-italiano de Lorenzo Franciosini Florentín (1620) señala que es un instrumento de cuerda con forma de violín (strumento di corde in forma di violino). En el mismo sentido se expresa el diccionario de español-inglés de Stevens (1706), que lo define como un "instrumento como un pequeño violín [fiddle], de solo una pieza ahuecada, cubierto con pergamino; lo tocan con sus dedos como la guitarra. Su sonido es muy punzante, pero funciona bastante bien en los conjuntos instrumentales [Consort]" (de no indicarse lo contrario, las traducciones son mías). El diccionario de la RAE en 1726 lo define como un instrumento "a modo de rabel pequeño con tres cuerdas. Es todo de una pieza cavada, con una tapa de pergamino, o hecho de propósito como la bandola o laúd. Hiérense las cuerdas de rasgado con los dedos, y aunque es rústico y tosco, entre otros instrumentos, sobresale con alegría”. Muy distinta es la definición del mismo diccionario en 1770: "Instrumento músico de cuatro o cinco cuerdas que se toca hiriéndolas con una púa de pluma. Es menor que la cítara y su buque compuesto de dos tablas planas que sirven de fondo y tapa: sube en disminución formando un cuello hasta el mástil que es muy corto y está dividido en seis o siete trastes, como el de la guitarra”. Seguramente esta última es la que corresponde a nuestro caso. 
cuatro órdenes [grupos de cuerdas]". ${ }^{27} \mathrm{El}$ diccionario de la RAE la define en 1734 como un instrumento de diez cuerdas, es decir, de cinco órdenes dobles. ${ }^{28}$ Esta definición se mantiene inalterada durante todo el siglo XVIII; pero ya en la edición de 1803 se afirma que el instrumento "ordinariamente se compone de cinco órdenes de cuerdas, aunque en el día ya se hace con seis y aun siete órdenes, y se llama guitarra de bajos". ${ }^{29}$ En síntesis, durante la mayor parte del período que nos ocupa la guitarra era un instrumento de cinco órdenes afinado en $\mathrm{Mi}$, como la guitarra actual; pero a fines del siglo XVIII coexistió con la nueva guitarra de seis órdenes e incluso, más raramente, con la de siete. Un ejemplo se halla en el inventario de bienes de Eugenio Núñez, realizado en Santiago en 1791, en el que se mencionan dos guitarras de seis órdenes (ver Tabla 1 ).

El término discante no figura en el diccionario de Covarrubias de 1611, pero sí en el diccionario de la RAE publicado en 1732, que lo define como una "especie de guitarra pequeña, que comúnmente se llama tiple”. En 1739, este mismo diccionario agrega que el tiple era "un instrumento especie de vihuela, y de su misma hechura, aunque más chico, porque tiene las voces muy agudas”. En otras palabras, estamos hablando de una guitarra más pequeña y aguda.

En cuanto al término vihuela, su significado es más ambiguo, porque varía según la época. Covarrubias la define en 1611 como un "instrumento músico y vulgar de seis órdenes de cuerdas". ${ }^{30}$ Casi un siglo después, el diccionario de español-inglés de Stevens (1706) la define como una especie de laúd con seis cuerdas, ${ }^{31}$ lo que es exacto porque, en su versión estándar, el instrumento tenía la misma afinación que un laúd de seis órdenes. En el caso chileno, el citado inventario del convento de la Merced de Santiago, realizado en 1676, hace una diferencia entre las dos vihuelas y la guitarra mencionadas; y todavía en 1691 el recibo de dote otorgado por Joseph de Lepe a Josepha Velasco (ver Tabla 1) distingue una guitarra de una vihuela. Sin embargo, a partir de 1739 el diccionario de la RAE nos dice que "según Covarr[ubias] era la lira antigua; pero hoy comúnmente vale lo mismo que guitarra". Este empleo del término como sinónimo de guitarra

27 Agrega además algo confuso: “... Tiene estas cuerdas requintadas, que no son unísonas, como las de [la] vigüela, sino templadas en quintas; fuera de la prima que está [sic, por esta] en ambos instrumentos, es una cuerda sola". Los tratados de la época no señalan que los órdenes del instrumento puedan afinarse en quintas, sino en unísonos u octavas.

28 "Instrumento músico de diez cuerdas, que se compone de un hástil [ sic], al cual está unido por sus cuatro lados el cuerpo de la guitarra, que es hueco, y por la parte de adelante tiene una abertura de figura circular, y más abajo una puentecilla, donde se atan las cuerdas, las cuales se aseguran en las clavijas que se ponen en la parte superior del ástil [sic], en el cual tiene sus trastes para subir o bajar las cuerdas y ponerlas en su punto armónico. Es tomado del francés Guitarre o Guiterre, que significa lo mismo".

29 Esta definición se modifica un tanto en 1843, cuando se suprime la opción de que el instrumento tenga siete órdenes. En el diccionario de Ramón Joaquín Domínguez, publicado en 1853, ya se la define como un instrumento de seis cuerdas, "y antiguamente de cinco". Sin embargo, ambas opciones (cinco o seis órdenes) permanecerán en el diccionario de la RAE hasta 1899, cuando el instrumento quede definido en su versión moderna como uno de seis cuerdas.

30 Covarrubias 1979: 1008.

31 "... a sort of lute that had six strings, and thence taken for a common lute". 
queda reflejado, entre otros, en el manuscrito musical de Antonio de Santa Cruz, conservado en la Biblioteca Nacional de España (M. 2209), el que a mi juicio puede fecharse en torno a 1700. Allí la guitarra de cinco órdenes se designa como "vigüela ordinaria". Volviendo al Santiago colonial, hallamos otro ejemplo en el citado inventario de bienes de Eugenio Núñez, ya que, en la almoneda o remate posterior, una de las guitarras de seis órdenes se designa como "vihuela" (ver Tabla 1). En resumen, durante la mayor parte del siglo XVII el término vihuela dio nombre a lo que podríamos definir como un laúd con forma de guitarra, es decir, un instrumento de seis órdenes afinado en Sol; pero hacia 1700 y durante todo el siglo XVIII se emplearía como sinónimo de guitarra.

Si consideramos la Tabla 1 con mayor detención, se aprecian otros aspectos de interés. En 1635 encontramos "cinco discantes de Lima" en la tienda de Blas Pinto Escobar; en 1657 una "guitarra hecha en Lima" entre los bienes del difunto indio cuzco Andrés Machado; y, en 1751, una "guitarra grande de Lima” en la dote de Rosa Salinas a su marido, Fermín de Quezada. De manera que una parte de las guitarras que había en Santiago hasta mediados del siglo XVIII era de origen limeño, hecho que no puede sorprender si se considera la notable influencia que la capital del virreinato tuvo en la vida musical santiaguina. ${ }^{32}$ Adicionalmente, un documento de 1786 conservado en el Archivo General de la Nación del Perú muestra el envío a Santiago, entre otros bienes, de "bordones [cuerdas graves] para guitarra” fabricados en Cádiz, dirigidos a Carlos de Vildósola y Salvador de Trucios, vecinos de dicha ciudad. ${ }^{33}$

A pesar de estos datos, la importación de guitarras a Chile en el siglo XVIII debió representar la excepción y no la norma, especialmente durante las últimas décadas. En los registros de entrada de navíos a Valparaíso, que he revisado íntegramente para el periodo 1769-1811, figuran decenas de claves, algunos órganos pequeños, un par de violines y uno que otro salterio traídos desde Lima, pero ninguna guitarra. ${ }^{34}$

Esto pudo deberse en parte a que, a esta altura, nuestro instrumento se fabricaba regularmente en Santiago, pues sabemos gracias a Pereira Salas que en 1789 existía allí un gremio de guitarreros. ${ }^{35}$ Aurelio Díaz Meza retrotrae la existencia de este gremio por lo menos a 1764, pues lo menciona en el marco de los festejos por la recepción del presidente Guill y Gonzaga, aunque no cita fuente alguna que respalde su afirmación. ${ }^{36}$ Asimismo, tenemos noticia de que hacia 1778 se

32 Sobre dicha influencia ver Vera 2004c; Vera 2005; Alruiz y Fahrenkrog 2008; Vera 2010; Vera 2012, y Vera 2013.

33 Archivo General de la Nación del Perú, Real Aduana, C 16.745-820 sin foliar.

34 Dichos registros se encuentran en los fondos Capitanía General y Contaduría Mayor (primera y segunda serie) del Archivo Nacional Histórico. El detalle de los instrumentos y objetos musicales encontrados para los años 1769-1799 puede verse en Vera 2010: 24-25.

35 Pereira Salas 1941: 226. Cf. con Subiabre 2006. Como afirma la autora, aunque Pereira Salas no cite fuente alguna, sin duda se basa en la relación de las fiestas por la asunción al trono de Carlos IV, que tuvieron lugar en dicho año.

36 Díaz Meza 1975: 179. 
fabricaban cuerdas para guitarra en la ciudad, ${ }^{37}$ por lo que su importación en 1786 por parte de Vildósola y Trucios no era fruto de una necesidad imperiosa, sino, tal vez, un signo de estatus social.

Paralelamente, durante el siglo XVIII el instrumento se vinculó de manera creciente con manifestaciones populares, en algunos casos perseguidas por la justicia. Pereira Salas recoge un documento de 1774 en el que se menciona a "algunas personas con guitarras en fandangos",38 y Laura Fahrenkrog cita una decena de expedientes judiciales que van de 1778 a 1809, en los que la guitarra aparece en bodegones y otros ambientes que podemos considerar como "populares". ${ }^{39} \mathrm{El}$ emplazamiento de la vivienda de los propietarios podría constituir otro indicio en tal sentido. Por ejemplo, la guitarra de María Márquez, encontrada en 1711 en su casa del barrio de La Chimba; 40 la de Manuel de Bezanilla, encontrada en 1777 en su chacra de La Cañadilla, ${ }^{41}$ o las dos guitarras que Eugenio Núñez tenía en 1791 en su finca de La Chimba, ${ }^{42}$ parecieran dar cuenta de un cultivo del instrumento en los sectores periféricos de la ciudad. ${ }^{43}$

Considerando esta creciente vinculación con lo popular, la ausencia de guitarras en los registros de navíos y su desaparición ya comentada de los conventos santiaguinos, queda claro que el instrumento no estaba entre los favoritos de la elite local en las últimas décadas del siglo XVIII. Lo que esto viene a reforzar es que dicha elite buscaba, con mayor perseverancia que un siglo atrás, diferenciarse claramente de los sectores subalternos. Después de todo, la guitarra siempre había tenido una presencia transversal en las distintas capas de la sociedad y no por ello había sido objeto del rechazo por parte de la cultura oficial que experimentó en esta época. Por tanto, la musicología confirma en este punto lo que historiadores como Alejandra Araya y Leonardo León han concluido en el campo de la historia, acerca de la creciente intolerancia de la elite santiaguina hacia lo popular. ${ }^{44}$ Frente a la actitud más centrada en el comportamiento o performance, que veíamos en los discursos sobre la guitarra en torno a 1700, hacia 1800 parece haber un retorno a los esencialismos ya observados a inicios del siglo XVII.

Sin embargo, el citado inventario de Eugenio Núñez nos muestra que en esta época no existía ya una sola guitarra, sino al menos dos: la tradicional de cinco órdenes y la nueva de seis órdenes. Incluso, hay referencias a guitarras adornadas

37 Fahrenkrog 2012: 56.

38 Pereira Salas 1941: 208.

39 Fahrenkrog 2011: 74-77, 80. De épocas anteriores, en cambio, solo un expediente de 1701 menciona a la guitarra (Fahrenkrog 2011: 73). Cf. con Fahrenkrog 2012: 38, 41, 44, 45, 46, 49, $50,54$.

40 Archivo Nacional Histórico, Escribanos de Santiago, vol. 470, fol. 236v.

41 Archivo Nacional Histórico, Escribanos de Santiago, vol. 820, fol. 335v.

42 Archivo Nacional Histórico, Escribanos de Santiago, vol. 854, fol. 25.

43 Sin embargo, este último aspecto no es concluyente, por cuanto también encontramos guitarras en manos de gente acaudalada, como la que el general Juan de Dios de la Cerda dejó en 1733 o la que Ignacio Hurtado tenía en 1774, en su casa ubicada "en la traza de esta dicha ciudad en parte notoria, sito cinco cuadras de la plaza mayor de ella hacia el este...”. Véase Archivo Nacional Histórico, vols. 537, fol. 226v y vol. 538, fol. 208v (Cerda); y Escribanos de Santiago, vol. 719, fol. 404 y vol. 883, fols. 51v y 178 (Hurtado).

44 Araya 1999, y León 2007. 
lujosamente, como la "Viguela grande con sus embutidos de concha de perla..." que Francisco Javier Errázuriz dejó en 1768, ${ }^{45}$ o la "guitarra de Jacarandá, con sobrepuestos de concha de perla y su caja”, tasada en cuarenta pesos, que el Marqués de la Pica tenía en su casa a comienzos del siglo XIX. ${ }^{46}$

De modo que, cuando en 1802 el convento de Santa Rosa de Curimón se esforzaba por quitar "la indecencia de la guitarrita", quizás el diminutivo no solo tuviese una connotación despectiva, sino que hiciese referencia específicamente a la guitarra más pequeña, de cinco órdenes. En otras palabras, es probable que en estos años la guitarra de cinco órdenes estuviese popularizada al punto de hacerla indeseable para los representantes de la elite local, mientras que la de seis órdenes, especialmente si estaba ornamentada, permaneciera en boga entre ellos.

\section{UNA NUEVA HIPÓTESIS ACERCA DEL ORIGEN DEL GUITARRÓN CHILENO Y EL CANTO A LO DIVINO}

Como es sabido, el guitarrón es uno de los instrumentos musicales más particulares y relevantes del Chile central. Emily Pinkerton, por ejemplo, le atribuye cierta cualidad "mágica", que estaría dada por su sonido y por las "infinitas preguntas" que despierta, "tanto sobre sus orígenes remotos como su evolución local...”; y, aunque asume sus "orígenes arcaicos", admite que "la historia distante del guitarrón puede permanecer en el misterio durante los años por venir". ${ }^{47}$ Mi propósito en esta sección es contribuir a esclarecer, aunque sea parcialmente, este "pasado indeterminado" del guitarrón, como lo llaman Bustamante y Astorga, ${ }^{48}$ proponiendo una hipótesis respecto de su origen que resulte convincente a la luz de la evidencia disponible.

El guitarrón chileno (ver Figura 2) es un instrumento de 25 cuerdas, con un clavijero más grande y un mástil más ancho y corto que el de la guitarra moderna. Estas cuerdas se distribuyen en cinco órdenes de distinto tamaño, más dos pares de cuerdas suplementarias llamadas "tiples" o "diablitos", que se ubican en los extremos superior e inferior del encordado. ${ }^{49}$ Tanto su forma como sus cinco órdenes de cuerdas permiten afirmar, según Pérez de Arce, que el guitarrón es una variante de la guitarra barroca, ${ }^{50}$ instrumento que, como hemos visto en la sección anterior, fue ampliamente usado en el Chile colonial.

45 Archivo Nacional Histórico, Escribanos de Santiago, vol. 777, fol. 76.

46 Fahrenkrog 2011: 83.

47 Pinkerton 2007: 12, 19, 46.

48 Bustamante y Astorga 1996: 5.

49 Pérez de Arce 2007: 22-25. Cf. Pinkerton 2007: 19-21, y Barros y Dannemann 1960: 10-14, quienes transcriben y amplían la descripción de Lenz 1919: 525-526. Mayor información, con una tabla comparativa de medidas entre los guitarrones de principios del siglo XX y más actuales, en Bustamante y Astorga 1996: 8-13.

50 Pérez de Arce 2007: 35. También Barros y Dannemann 1960: 3-4, relacionan al guitarrón con la guitarra de cinco órdenes, pero vinculan sus cuerdas fuera del batidor o diablitos con el "chitarrone" o tiorba. Grebe 1967b: 43-45, por su parte, plantea que el guitarrón puede vincularse con las "guitarras 


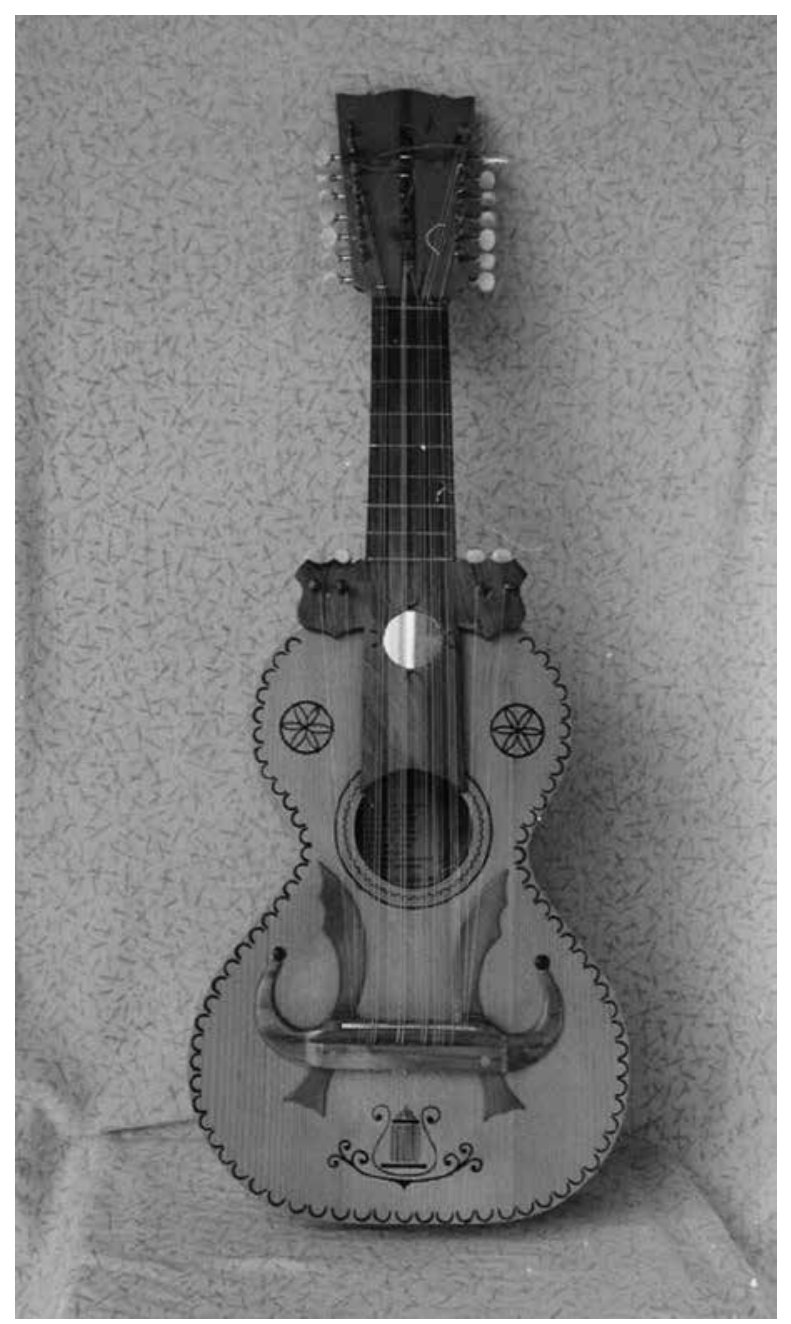

Figura 2. Guitarrón chileno.

Sin embargo, existen características que son exclusivas del guitarrón: el uso de los "diablitos" o cuerdas al aire, que suelen afinarse en la tónica y la dominante; la combinación de cuerdas de nylon (y antiguamente tripa), metal y entorchadas sobre seda o metal; y, sobre todo, su encordadura, que combina órdenes de distintos tamaños, de dos a seis cuerdas cada uno afinadas en unísonos, octavas y dobles octavas. Todo ello da lugar a “... esquemas armónicos de estructura compleja, con una gran sonoridad, amplitud de registro, densidad de armónicos

arcaicas" de cuatro y cinco órdenes, pero relaciona el empleo de bordones con cordófonos medievales como la viela (fiddle). 
y variedad tímbrica". ${ }^{51}$ Estas características sonoras son atribuidas por Pérez de Arce a la influencia del pueblo que habitaba el Chile central antes de la llegada del español: los picunches. De su cultura habría llegado a nuestros días la tradición de los "bailes chinos", un sistema musical basado en flautas de "sonido rajado", "fuerte, disonante, con gran cantidad de armónicos, redobles y batimentos...". Este enriquecimiento y a la vez sutil diferenciación de los timbres sería, según dicho autor, un rasgo compartido entre el guitarrón chileno y los bailes chinos, lo que explicaría que el rango de dispersión de ambos sea similar. ${ }^{52}$

A modo de síntesis, según esta hipótesis, el guitarrón sería una variante de la guitarra barroca, pero con diferencias significativas que se explicarían por la influencia de las culturas aborígenes del Chile central.

Con algún matiz, ${ }^{53}$ estoy de acuerdo con la primera parte de la hipótesis. Primero, porque ya en 1555 el teórico español Juan Bermudo afirmaba que habían llegado de Indias "bandurrias con cinco cuerdas", lo que demuestra que los instrumentos afines a la guitarra fueron objeto de modificaciones en América desde una época muy temprana. ${ }^{54}$ Segundo, porque son demasiados los elementos que vinculan al guitarrón con la guitarra barroca, aparte de los cinco órdenes mencionados: 1) la tendencia a apoyar el dedo meñique de la mano derecha en el puente o muy cerca de él;55 2) el uso exclusivo del pulgar, el índice y el medio de dicha mano; ${ }^{56} 3$ ) la ambigüedad respecto de las inversiones de los acordes, dada por la presencia de octavas en algunos órdenes; ${ }^{57}$ y 4) el uso entre los guitarroneros de términos arcaicos empleados por lo menos desde el siglo XVIII, como "alambre" y "bordones" para referirse a las cuerdas de metal y entorchadas.

De esto último puedo ofrecer algunos ejemplos de interés. En el inventario de bienes de Manuel Arias y Joseph Antonio Fonteroza, realizado en Santiago en 1781, se encontró una cajita de "alambre encordadura de clave";58 en el de Domingo Pérez de Riobó, además de una "guitarra nueva”, se encontró "un papel de bordones de arpa" (ver Tabla 1); y en los registros de entrada de navíos a Lima, conservados en el Archivo General de la Nación del Perú, se mencionan grandes cantidades de "alambre" para clave y monocordio, así como "bordones"

51 Pérez de Arce 2007: 22-27, 30-31.

52 Pérez de Arce 2007: 43, 45, 46.

53 Pérez de Arce 2007: 40, afirma que en Europa los órdenes de tres o más cuerdas se encuentran solo en los instrumentos percusivos, como el salterio, y no en la familia de la guitarra. Si bien esta afirmación es cierta de un modo general, hay algunas excepciones, como las guitarras batentes del siglo XVIII con órdenes triples, que se conservan, entre otros, en el Museu de la Música de Barcelona.

54 Ver Marín 2007: 205.

55 Pérez de Arce 2007: 29. Al parecer, esta práctica era predominante hace algunos años, pero en la actualidad ha comenzado a decrecer; ver Mendoza 2009: 23. Santiago de Murcia señala en 1722 que dicha práctica era común entre los principiantes; ver Murcia 2010: xxxiv.

56 Esto es práctica común en Pirque en la actualidad, según señala Pinkerton 2007: 100-101. Según Santiago de Murcia, estos eran los dedos con los que debía tocarse la guitarra barroca; Murcia 2010: 5.

57 Pérez de Arce 2007: 30. Para Russell, en la música para guitarra barroca frecuentemente los acordes se mezclan en un contexto sin una octava o registro claro (“... melt into one octaveless class”); ver Russell 1981: 85.

58 Archivo Nacional Histórico, Escribanos de Santiago, vol. 886, fol. 105v. 
o "entorchados" para guitarra y violín, importados desde España y el resto de Europa. ${ }^{59}$ Además, María Ester Grebe señaló en su momento el uso, entre los cantores y guitarroneros, de términos comunes con los libros para vihuela del siglo XVI, como "cayda", "quiebro" (o "requiebre") y "redoble". 60

Un último arcaísmo lingüístico fue documentado por Barros y Dannemann en Puente Alto hacia 1960 y consiste en designar a la tercera cuerda u orden del guitarrón como "requinta". Según estos autores, ninguno de sus "informantes" supo explicarles su significado, ${ }^{61}$ pero el diccionario de la RAE permite aclarar el punto, pues a partir de 1803 define "requintar la guitarra" como el recurso empleado cuando, por faltarle al instrumento la primera cuerda, se bajan "medio punto las terceras para hacer los mismos puntos que si tuviera prima con las otras cuerdas". En otras palabras, bajando medio tono el tercer orden pueden ejecutarse los mismos acordes con las cuerdas restantes, pero suenan a una distancia de quinta ascendente con relación a la afinación estándar (Re mayor pasa a ser La Mayor, etc.). La designación del tercer orden o cuerda como requinta denota así lo habitual que debió ser esta práctica entre los guitarroneros en ciertos momentos de su historia, sin duda por la frecuencia con la que el primer orden se cortaba.

Asumiendo el parentesco entre la guitarra barroca y el guitarrón, es probable que las once "guitarras grandes" mencionadas en los inventarios santiaguinos del siglo XVIII (ver Tabla 1) fuesen guitarrones. Estas menciones se remontan a 1701, por lo que no corresponden a las guitarras de seis o siete órdenes que se introdujeron en los últimos años de dicho siglo. En ese caso, es posible que lo que hoy conocemos como guitarrón chileno fuese inventado -o desarrollado-62 por alguno(s) de los guitarreros activos en Santiago en torno a 1700. Esto explicaría su dispersión en la zona central y especialmente en sectores cercanos a la ciudad, como Melipilla, pues si había un centro en el Chile colonial capaz de irradiar sus prácticas culturales a diversas localidades, ese era justamente Santiago. Recordemos además que, según Barros y Dannemann, hay indicios de que durante buena parte del siglo XIX el guitarrón todavía era cultivado en la capital y solo hacia 1900 habría quedado relegado a las "regiones adyacentes" ${ }^{63} \mathrm{El}$ problema de esta hipótesis es que, al no conocer las características específicas de las guitarras grandes mencionadas en los inventarios, es posible simplemente que fuesen guitarras barrocas de

59 Ver detalles en Vera, "De modernas oberturas para orquesta y antiguos minuetos para guitarra: nuevas luces sobre la recepción de la música instrumental europea en Lima a finales del siglo XVIII", en preparación.

60 Grebe 1967a: 334.

61 Barros y Dannemann 1960: 34.

62 En efecto, el proceso pudo ser bastante más complejo que la simple invención por parte de un solo constructor. Por ejemplo, varios fabricantes pudieron comenzar a experimentar con guitarras de mayor tamaño, cuyos diseños fueron modificándose a lo largo del tiempo, hasta llegar a constituir un modelo como el que conocemos hoy.

63 Barros y Dannemann 1960: 10. Los autores dicen basar su afirmación en los datos contenidos en las obras de Antonio Acevedo, Rodolfo Lenz, Diego Muñoz y otros, pero admiten que se trata de una conjetura. 
mayor tamaño, como existían en España y en otras partes de Europa. ${ }^{64}$ Aunque este punto quede abierto, la relación entre el guitarrón actual y la antigua guitarra de cinco órdenes resulta difícil de cuestionar.

Por el contrario, en relación con la segunda parte de la hipótesis -acerca del supuesto vínculo entre la variedad tímbrica del guitarrón y los bailes chinos-, creo posible proponer una explicación más plausible, que requiere desviarnos momentáneamente del instrumento mismo, para prestar atención a las prácticas musicales y poéticas a las que está vinculado actualmente. Estas suelen englobarse con la expresión "canto a lo poeta", que incluye tanto al "canto a lo humano" como al "canto a lo divino". Pero si bien hoy el guitarrón es usado indistintamente en una y en la otra práctica, sabemos por el testimonio de Santos Rubio que a mediados del siglo XX se tocaba sobre todo en velorios de angelitos y vigilias, e incluso en nuestros días el canto a lo divino constituye, según Pinkerton, la práctica más importante asociada al instrumento en la zona de Pirque. ${ }^{65}$ Por tanto, un acercamiento al canto a lo divino puede resultar crucial para comprender los orígenes del guitarrón.

Sus características generales son bien conocidas gracias a estudios anteriores. ${ }^{66}$ Se trata de una "expresión religiosa-musical" consistente en "la entonación de poesía estrófica”, generalmente en décimas y "con temáticas pertenecientes a la tradición católica"; su práctica se concentra "principalmente en la zona central rural de Chile" y se vincula con "la oración, evangelización, rito y culto". Aunque actualmente se lleva a cabo en casas particulares o iglesias, su presencia en estas últimas es un fenómeno reciente, que debe mucho a la labor del sacerdote e investigador Miguel Jordá. ${ }^{67}$

Desde un punto de vista musical, María Ester Grebe distingue dos grandes estilos (tanto en el canto a lo humano como a lo divino): un estilo estricto -caracterizado por una tendencia rítmica hacia la regularidad y una marcada simetría en el agrupamiento de las frases o períodos- y un estilo libre. Respecto de este último afirma:

"muestra un ritmo que no tiende a ser métrico, que es predominantemente irregular y que sigue de cerca la forma de una oración. En este estilo hallamos una gran flexibilidad en las dimensiones y los agrupamientos de las frases y períodos, los cuales evitan la simetría, y un apreciable grado de variación en las fórmulas melódicas: son modificadas ligera o moderadamente, mas nunca de forma extrema. Este estilo presenta obvios mecanismos improvisatorios, y predomina en él un tipo de recitación salmódica interrumpido por cadencias características". ${ }^{68}$

64 De hecho, el diccionario de la RAE define en 1734 el término "guitarrón" como una "guitarra grande”, sin duda para referirse a guitarras de cinco órdenes de mayor tamaño, pero no al guitarrón chileno actual.

65 Pinkerton 2007: 120, 176. También Grebe, entre otros, señala que el género a lo divino es "más antiguo y considerado más importante que el género humano" (1967b:16).

66 Entre otros, Uribe Echevarría 1962; Jordá 1973; y Mendoza 2009.

67 Mendoza 2009: 7.

68 Grebe 1967b: 51. 
Contra el gran interés que ha despertado su práctica actual, su historia pasada ha recibido una atención escasa. Pereira Salas publicó en 1962 un breve artículo pertinente a "los orígenes del canto a lo divino", en el que aporta interesantes datos del cultivo de la poesía en el Chile colonial. Cita, por ejemplo, al abate Molina, quien en su Compendio de la historia civil del reino de Chile, publicado en España a fines del siglo XVIII, señala que entre las "gentes de campo" son comunes "los compositores de repente, llamados en su lengua del país palladores", y que "estos son muy buscados; así cuando conocen tener ese talento, no se aplican a otros oficios" ${ }^{69}$ Pese a ello, no hay dato alguno en el texto de Pereira Salas acerca de la práctica del canto a lo divino propiamente tal.

Otros autores, como María Ester Grebe, Miguel Jordá, Bustamante y Astorga, y Víctor Rondón han atribuido el origen del canto a lo divino a las misiones jesuíticas, ${ }^{70}$ idea que es compartida por algunos cantores actuales, como Alfonso Rubio. ${ }^{71}$ Sin embargo, los argumentos en tal sentido son demasiado generales. Aunque la catequesis llevada a cabo por dicha congregación incluía la música, se postula que puede haber dado lugar al canto a lo divino; pero no se ha conseguido establecer analogías más precisas que avalen esta hipótesis. De hecho, el propio Rondón admite que los contenidos teológicos e históricos del canto a lo divino no se hallan en las oraciones básicas y el catecismo usados por los antiguos misioneros. ${ }^{72}$

En cambio, hay otro aspecto del canto a lo divino que a mi juicio resulta de mayor relevancia: su combinación del lenguaje tonal con giros melódicos propios de modos antiguos como el mixolidio. ${ }^{73}$ María Ester Grebe atribuye esta característica, principalmente, a la influencia de la música para vihuela del siglo XVI, traída a Chile por los soldados y religiosos de la época, ${ }^{74}$ así como a la música vocal de la Edad Media (la Chanson de geste y las cantigas) y el Renacimiento (los cancioneros españoles). Y aunque admite una posible relación con los "tonos salmódicos gregorianos", dada por "estrechas similitudes morfológicas", a falta de documentación histórica considera dicha relación como "menos obvia" y "totalmente hipotética". ${ }^{75}$ Uribe Echevarría, por su parte, afirma que el canto a lo divino "Recuerda vagamente el canto llano de las catedrales, en los oficios de Semana Santa" ${ }^{6}$. En la misma línea, Luis Gastón Soublette señala que "La melodía del verso es casi siempre salmódica, es decir, sin pie rítmico, con todas las características del recitativo". ${ }^{77}$ Por su parte, Manuel Dannemann plantea que "La melodía [del canto a lo divino] tiene un ámbito reducido, con intervalos pequeños, y cuando

69 Pereira Salas 1962: 48.

70 Grebe 1967a: 337; Jordá 1973: 10; Bustamante y Astorga 1996: 14, y Rondón 2009: 519-524.

71 "Los jesuitas llegaron con todas las ganas de enseñar, y nosotros, la escasa cultura que tenemos es la que nos dejaron ellos...". Citado por Mendoza 2009: 43.

72 Rondón 2009: 519.

73 Grebe 1967b: 58.

74 Grebe 1967a.

75 Grebe 1967b: 55, 57, 75, 77 .

76 Uribe Echevarría 1962: 34.

77 Uribe Echevarría 1962: 35. 
la rítmica es irregular o libre, se parece a la del salmódico canto llano, con el refuerzo de los elementos modales que suelen hacerse presente..." ${ }^{78}$

Sin ánimo de restar valor al admirable estudio que Grebe realizó para vincular la música de tradición oral de Chile con la música de la Edad Media y el Renacimiento, creo que la tendencia a buscar el origen de las manifestaciones tradicionales en el pasado más remoto posible (en este caso la conquista española) ${ }^{79}$ refleja una premisa que durante mucho tiempo prevaleció entre quienes practicaban la etnomusicología: que las prácticas de tradición oral tendían al estatismo, es decir, a transmitirse de manera relativamente estable de generación en generación, de modo que sus características esenciales debían proceder, necesariamente, del tiempo que las había visto nacer. Ciertamente se trataba de una premisa romántica, ya que implicaba que dichas prácticas eran puras, auténticas e incólumes. ${ }^{80}$

Sin embargo, mucho antes de que Grebe publicara sus hallazgos el estudioso alemán Rodolfo Lenz había demostrado, en su estudio pionero respecto de la poesía popular impresa, que las cosas podían suceder de manera muy distinta. Según este autor, durante el primer tiempo de su estadía en Chile se vio sorprendido al encontrar en la obra de Bernardino Guajardo y algunas hojas sueltas "décimas referentes al ciclo épico de las chansons de geste francesas de Carlomagno”. Pero más adelante encontró la fuente más probable para dichas décimas: dos ediciones modernas (1890 y 1893) publicadas en Chile de un antiguo libro de caballería referido exactamente a dicho ciclo. ${ }^{81}$ En otras palabras, la poesía popular en torno a 1900 sí tenía influencia de la lírica medieval, pero esta era indirecta y muy reciente, mediante la filología de fines del siglo XIX. El hallazgo de Lenz demuestra que algunos de los rasgos que conforman una práctica cultural en el presente podrían haberse introducido en cualquier punto de su historia y también -por qué no- a lo largo de procesos más complejos de varios años o décadas.

Considerando lo anterior, y a diferencia de Grebe, pienso que Soublette y Dannemann aciertan cuando comparan el canto a lo divino con la salmodia, término que designa la práctica de cantar los salmos y otros textos litúrgicos con fórmulas melódicas estandarizadas, aunque flexibles, llamadas "entonaciones". Por lo general, estas fórmulas agrupan dos versículos y llevan dos cadencias, una intermedia y otra final. El resto lo ejecuta el cantor libremente, sobre una misma nota que se repite cuantas veces sea necesario para declamar el texto. Por tanto, es con este tipo de canto llano que el canto a lo divino se relaciona más directamente.

Los tratados de los siglos XVI a XVIII confirman que la rítmica del canto salmódico estaba regida fundamentalmente por la versificación del texto. Así lo expresa el teórico Pietro Cerone en su conocido tratado Melopeo y maestro, de 1613:82

78 Dannemann 1974: 284. Las cursivas son mías.

79 Dando por establecido que el pasado prehispánico aparecía como una opción menos probable, aunque Grebe no dejara de mencionarla en su discusión (1967b: 11).

80 Cf. Stobart 2009: 103.

81 Lenz 1919: 590-591. Lenz afirma que la versión original del texto, en alemán, fue escrita por él en 1894.

82 Cerone 1613: 414. 
"El compás de los salmos no mira hacer todos los puntos iguales, sino va midiendo todas las sílabas breves y longas, según las reglas gramaticales: de forma que tanto tiempo gasta en una longa, como en dos breves, poco más o menos. El que en la Salmodia hubiere de llevar al compás, no solamente ha de ser buen cantor, sino también buen latino: entendiendo esto de Compás igual, y los puntos desiguales. Una vez entran en un compás dos puntos, otra vez tres. En todo y por todo en la Salmodia se debe guardar el acento, especialmente en la demediación de los versos, y en las secuencias...”.

Este tempo libre, subordinado al texto, es también mencionado por otros teóricos de la época, como Juan Bermudo (1555), Vicente Villegas (1604) y Andrés de Monserrate (1614). ${ }^{83}$

Otro rasgo común entre ambos tipos de canto se halla en las cadencias. Como es sabido, las entonaciones del canto a lo divino son bastante libres, pero uno de sus rasgos estables está dado por las cadencias resolutivas descendentes en la cuarta y décima línea estrófica. ${ }^{84} \mathrm{Si}$ consideramos las entonaciones prescritas por Cerone en $1613,{ }^{85}$ que son las mismas que figuran en el tratado de Nassarre un siglo más tarde, ${ }^{86}$ su rasgo más estable se halla en las cadencias resolutivas, que son siempre descendentes. Lo contrario ocurre en los inicios. En su versión más solemne, las entonaciones salmódicas añaden una fórmula melódica inicial que es siempre ascendente y abarca intervalos de tercera, cuarta o quinta, dependiendo del tono, ${ }^{87}$ un rasgo que también podemos ver en algunas entonaciones del canto a lo divino, que comienzan con giros ascendentes, aunque los intervalos se amplíen hasta una octava e incluyan a veces glissandi intermedios. ${ }^{88} \mathrm{Si}$ bien la variedad de entonaciones posibles y sus variantes exceden aquellas listadas por Cerone y Nassarre ${ }^{89}$ el hecho de recurrir a estos teóricos está respaldado por el conocimiento que se tenía de ellos en Chile y el virreinato del Perú. El tratado de Cerone se encontraba hacia 1722 en manos de Matías Livisaca, músico de la parroquia de Santa Ana en Cuzco, quien lo legó a Antonio Durán de la Mota, maestro de capilla en Potosí. ${ }^{90} \mathrm{El}$ tratado de Nassarre, por su parte, figura en un inventario de la biblioteca de los franciscanos de Santiago de Chile realizado en 1799. ${ }^{91}$ Incluso uno de sus volúmenes aún se conserva en el convento principal de la orden, con anotaciones que retrotraen su uso por lo menos a $1762 .{ }^{92}$

83 Robledo 2012: 301-302.

84 Barros y Dannemann 1960: 35; Grebe 1967b: 52; Dannemann 1974: 283-284; Pinkerton 2007: 87-91.

85 Cerone 1613: 353-356.

86 Nassarre 1724: 178-188.

87 Cerone 1613: 355.

88 Uribe Echevarría 1962: 34; Mendoza 2009: 11.

89 Como lo prueba, entre otros, el libro de Ferretti 1938: 129-346. Agradezco a David Andrés Fernández el haberme facilitado esta fuente.

90 Baker 2008: 182.

91 Vera 2005: 29.

92 Pude consultar este ejemplar el 12 de octubre de 2010 en la biblioteca conventual, gracias al padre Rigoberto Iturriaga, entonces archivero del convento. Se hallaba en una repisa superior que llevaba en lo alto el número 28 y debajo un letrero escrito a mano, con la indicación "Música moderna siglo XVIII". 
Sin perjuicio de que sea posible ampliar la búsqueda a otras entonaciones salmódicas, aquellas transcritas por Cerone y Nassarre son suficientes para revelar analogías incluso más específicas. La entonación del canto a lo divino conocida como "La dentradora" presenta claras semejanzas con la entonación del octavo tono para los días "simples y feriales", que encontramos en el tratado de Cerone. ${ }^{93}$ La versión del cantor Francisco Astorga, en una décima "Por salutación a la cruz" transcrita por Esteban Mendoza, ${ }^{94}$ resulta elocuente. A pesar de estar en Sol Mayor, la declamación del texto se realiza predominantemente sobre la nota Do, para concluir con una fórmula cadencial que enfatiza las notas Do, La y Sol (ver ejemplo 1). ${ }^{95}$ Análogamente, la entonación transcrita por Cerone comienza con la repetición del Do y concluye con una fórmula cadencial muy similar a la empleada por Astorga (ver ejemplo 2).

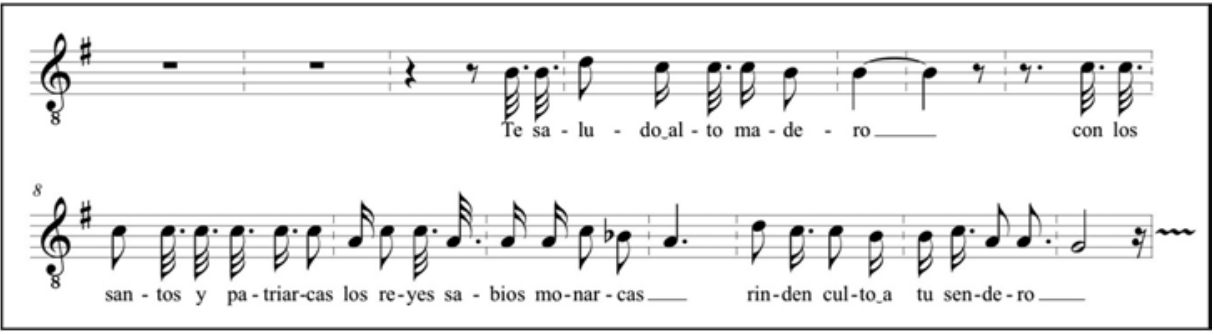

Ejemplo 1

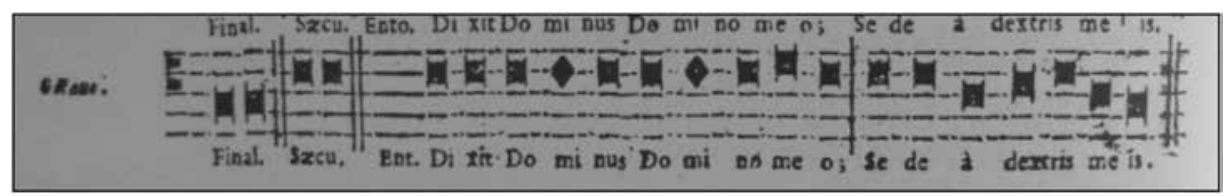

Ejemplo 2

Además, he encontrado otras similitudes, quizás menos claras, pero dignas de señalar. Primero, el inicio de la entonación conocida en el canto a lo divino como "La rosa y romero", con su arpegio ascendente y posterior ascenso al sexto

93 Cerone 1613: 354. De las entonaciones mencionadas por Cerone y Nassarre para diversos tipos de texto, he encontrado relaciones significativas solo con las entonaciones de los salmos, tanto en las "feriales" como en aquellas "para los salmos solennes [sic] y festivos". Estas corresponden a los "ocho tonos de la salmodia de los introitos y las comuniones", que Ferretti 1938: 278-280 extrae de la edición vaticana del gradual. Las importantes variantes con relación a las transcripciones de Cerone y Nassarre parecen dar cuenta de modificaciones sufridas por dichas entonaciones entre el siglo XVIII y la primera mitad del siglo XX, cuando el libro de Ferretti fue escrito.

94 Mendoza 2009: 42-43.

95 En la transcripción de las entonaciones del canto a lo divino he mantenido los criterios empleados por los autores citados, en cuanto a ritmos y demás aspectos de orden musical. En el caso de las de Bustamante y Astorga, he aplicado el texto -que en su edición figura por separado- a las notas correspondientes. 
grado (ver ejemplo 3), ${ }^{96}$ resulta muy similar al inicio de la entonación del quinto tono para los salmos solemnes y festivos, transcrita por Cerone (ver ejemplo 4). ${ }^{97}$

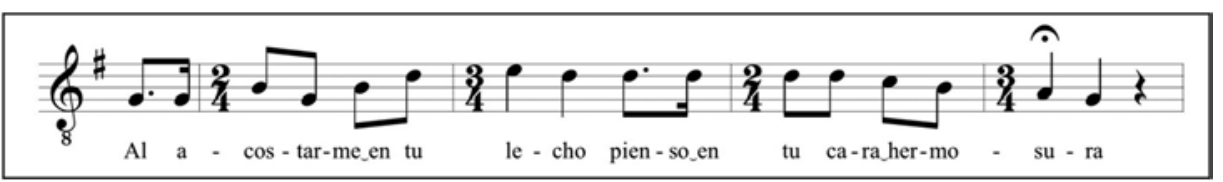

Ejemplo 3

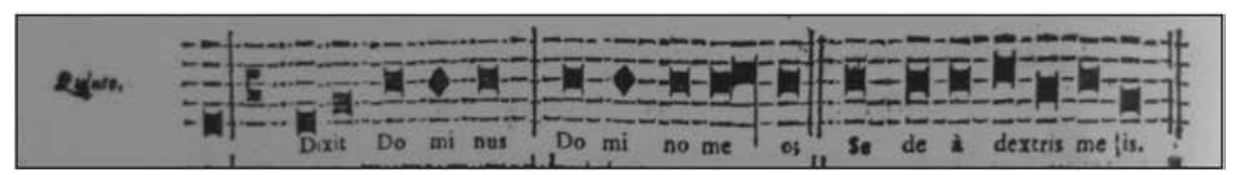

Ejemplo 4

Segundo, la frase inicial de la entonación conocida actualmente como "La huemulina" (ver ejemplo 5) ${ }^{98}$ presenta una relativa semejanza con la entonación del séptimo tono para los salmos solemnes y festivos, transcrita por el propio Cerone (ver ejemplo 6).${ }^{99} \mathrm{El}$ protagonismo de las notas Do y Fa en la frase inicial, junto al descenso gradual de Mi a La en la parte final son los puntos que se deben destacar.

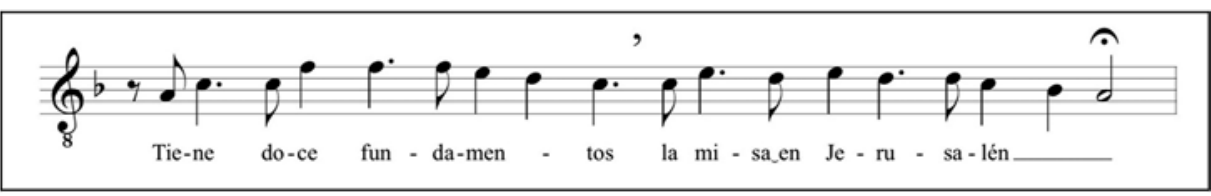

Ejemplo 5

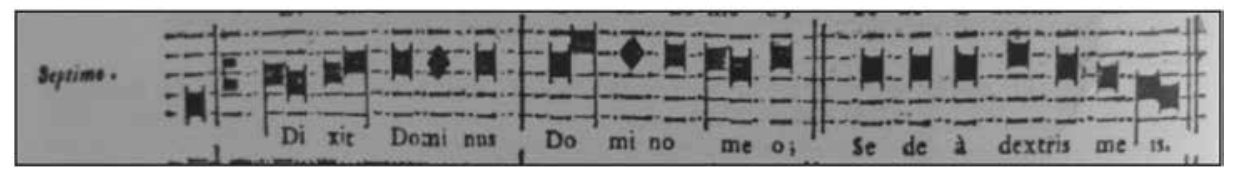

Ejemplo 6

Finalmente, la entonación conocida como "La tres fulminante" (ver ejemplo 7 $)^{100}$ se asemeja a la antigua entonación del primer tono para los días solemnes y festivos (ver ejemplo 8). ${ }^{101}$ En la primera parte de ambas entonaciones la melodía se mueve en torno al tercer grado, con idas y vueltas a los grados dos y cuatro. Además, la parte final presenta cierta similitud por su insistencia sobre el quinto

96 Ver la transcripción de Bustamante y Astorga 1996: 39-40.

97 Cerone 1613: 356.

98 Bustamante y Astorga 1996: 69.

99 Cerone 1613: 356.

100 Bustamante y Astorga 1996: 70-71.

101 Cerone 1613: 355. 
grado del pentacordio, para luego descender hasta el primero. Este posible vínculo podría explicar también la ambigüedad tonal: mientras que la línea vocal de "La tres fulminante" comienza en La Mayor pero termina en Mi Mayor, la entonación salmódica, desde una perspectiva tonal, comienza en Fa Mayor pero termina en Re menor.

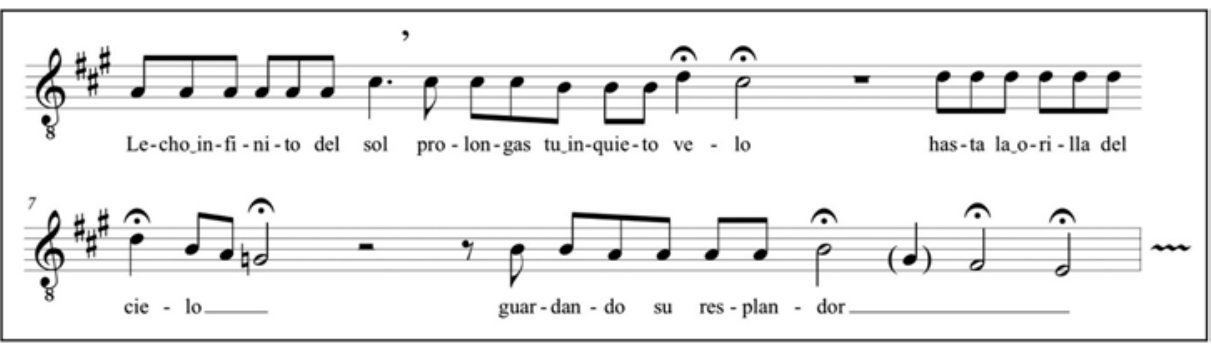

Ejemplo 7

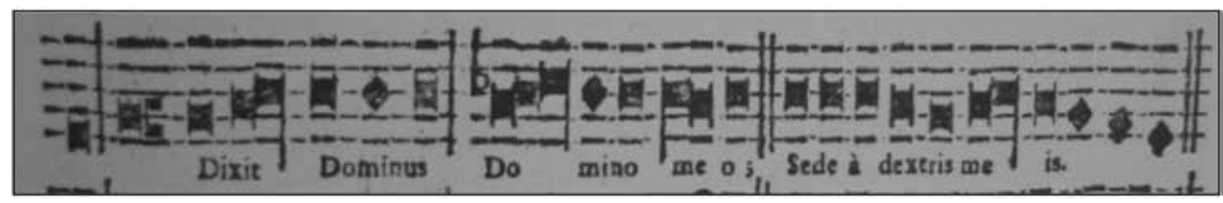

Ejemplo 8

Posiblemente un trabajo más detallado podría arrojar coincidencias parecidas en relación con otras entonaciones, pero los casos señalados, especialmente el de "La dentradora", parecen suficientes para pensar que las entonaciones del canto a lo divino han conservado de las antiguas entonaciones salmódicas algunos de sus rasgos característicos.

Pero ¿es posible relacionar estas semejanzas, derivadas de un análisis formal, con la evidencia histórica conocida? O, dicho de otra forma, ¿es posible plantear que estas semejanzas a nivel formal se relacionan con la supervivencia de prácticas coloniales?

En este punto considero muy interesante un documento que encontré hace años en el Archivo General de Indias, pero hasta ahora no lo había relacionado con el tema de este trabajo. En 1609 el obispo de Santiago, Juan Pérez de Espinoza, envió al rey un informe en el que afirmaba que su catedral tenía necesidad, entre otras cosas,

"de unos órganos, porque los que tiene son muy pequeños y están medio desbaratados e podridos de salitre [sic] y en esta tierra no hay quien los sepa aderezar; y también tiene necesidad de libros de canto, porque en el coro se canta por unos papeles que tiene el sochantre y las más antífonas del año se dicen en tono y no en canto llano porque no hay libro apuntado sino de solamente de [sic] algunas festividades..."102

102 Archivo General de Indias, Chile, vol. 65, sin foliar. Las cursivas son mías. 
En otras palabras, el hecho de no contar con libros de coro suficientes obligaba a los cantores de la catedral a ejecutar una gran parte de la música litúrgica por medio de entonaciones salmódicas ("en tono"); y no solo en el caso de los salmos y demás cánticos en los que esto era práctica frecuente, sino también en el caso de otros textos litúrgicos que contaban con melodías específicas en los libros de canto llano. Este uso es confirmado por Cerone, al inicio de la sección dedicada a las entonaciones, cuando afirma que abordará "el tono o modo para cantar las oraciones, profecías, epístolas, evangelios y otras cosas sin libro puntado...”; y, más adelante, añade que "para cantar semejantes cosas perfetamente [sic], no se requiere tanto el arte musical, cuanto una gracia natural, la cual ha de ser simple y sin afectación”. 103

Lo interesante es que el canto litúrgico por medio de entonaciones siguió siendo una práctica, si no predominante, al menos muy relevante en la catedral de Santiago durante todo el siglo XVII. Prueba de ello es que en sus constituciones de 1689, promulgadas por el obispo Bernardo Carrasco y publicadas dos años más tarde junto al sínodo diocesano, se ordena lo siguiente ${ }^{104}$ :

"Cantáranse siempre las primeras y segundas vísperas, todas las fiestas de Cristo Señor nuestro y su Madre Santísima, las de los Apóstoles y de Ángeles, las de la Santa Rosa, San Saturnino, y la Dedicación y Consagración de esta Iglesia, que fue a diez y nueve de Otubre [sic] de ochenta y siete; y porque este Coro no puede sustentar cantores y Capellanes, ni los tiene, se dirán en tono los Maitines de las festividades referidas, menos las Pascuas de Navidad, y Resurrección, que entonces serán todos cantados...”.

El documento continúa especificando otras partes del oficio y celebraciones que debían "decirse en tono", contra la práctica-supuestamente más habitual-de "cantarse", es decir, de interpretarse en canto llano (o polifonía).

Estas disposiciones fueron recogidas en 1763 por el obispo Manuel Alday, cuando ordenó reimprimir las constituciones de Carrasco y observarlas en todo lo que no contraviniese a las que él mismo había dictado en el sínodo de aquel año. ${ }^{105}$

Más adelante (septiembre de 1788), en el marco de una reforma a la capilla de música de la catedral de Santiago que incrementó sus sueldos y el número de instrumentistas, el cabildo dejó estipulado que el primer sochantre debía ensenar a los cantollanistas a "entonar" himnos, introitos y otras partes de la misa;106 expresión que sin duda refiere también al canto en tono.

Podemos pues asumir que, en el siglo XVIII, sin perjuicio de existir ya una capilla estable de cantores e instrumentistas en la catedral, 107 el canto en tono seguía teniendo una importancia similar a la que el obispo Carrasco había prescrito a fines del siglo XVII.

103 Cerone 1613: 365, 396. Las cursivas son mías.

104 Carrasco 1691: 61v.

105 Carrasco 1764.

106 Así como a "salmiar" (cantar o entonar los salmos). Ver Archivo de la Catedral de Santiago, Acuerdos del cabildo, vol. 3, fols. 159-161.

107 Ver al respecto Vera 2009: 297-301. 
En mi opinión, los testimonios anteriores dan buena cuenta de cómo se practicaba el canto litúrgico en la época colonial. En aquellas iglesias en las que no existía un corpus de libros corales o este era muy reducido, más aún si no había una capilla musical propiamente dicha, las entonaciones salmódicas se emplearían con una frecuencia mayor que la habitual. ${ }^{108}$ De ser este el caso en la catedral de Santiago, es factible imaginar que constituiría una práctica predominante en muchas iglesias del Chile central, especialmente rurales, ya que dicha catedral constituía la cabeza de todo el obispado en la época colonial.

El lector podrá suponer hacia dónde va mi argumentación. Considerando la presencia de la guitarra en algunas iglesias de Santiago y el Chile central durante los siglos XVII y XVIII, que ha sido documentada en la sección anterior, parece razonable pensar que en muchas de ellas la música litúrgica solía cantarse mediante entonaciones, acompañada por la guitarra de cinco órdenes en sus diversos tamaños y formas, las que posiblemente incluían al guitarrón. Sin embargo, hemos visto en la sección anterior que hacia fines del siglo XVIII la guitarra fue progresivamente vinculada con manifestaciones populares y que esto tendió a alejarla de los sectores de elite, caracterizados en esta época por una creciente intolerancia hacia dichas manifestaciones. ${ }^{109}$ Hemos visto también que en el convento franciscano de Santa Rosa de Curimón se instaló un órgano en 1802 para quitar "la indecencia de la guitarrita", seguramente en alusión a la guitarra de cinco órdenes. Por tanto, es probable que este instrumento y sus variantes fuesen extirpados incluso de las iglesias rurales en torno a 1800 y, de esta forma, la práctica de entonar el canto sagrado con acompañamiento de guitarra o guitarrón quedó confinada a las casas particulares y ceremonias de carácter privado. Todo ello dio origen, al menos en parte, a lo que hoy conocemos como "canto a lo divino".

Esto me lleva de vuelta a la variedad tímbrica del guitarrón, dada por los distintos tamaños de sus órdenes, cuerdas de diversos materiales y la inclusión de octavas y dobles octavas. Mientras que Pérez de Arce atribuye esta cualidad a las culturas prehispánicas del valle central, la misma variedad tímbrica existe en otro instrumento, europeo y occidental, que era bien conocido en el Chile colonial; solo que no se trata de un instrumento de cuerda, sino de teclado: me refiero al órgano. En él era posible obtener octavas y dobles octavas con solo pulsar una tecla, además de numerosos efectos adicionales. Por ejemplo, en 1611 se construyeron para la catedral de Santiago y el convento de San Agustín órganos que tenían, entre otros, registros agudísimos como el de "churumbela" y otros con carácter festivo como el de "pajaritos". ${ }^{110}$

108 Además, el canto en tono era empleado por ciertas órdenes religiosas porque estaba asociado con una mayor devoción y austeridad; ver Baade 2002: 38. Quizás por esta razón un documento de 1690 ordena que los franciscanos recoletos de Santiago "no canten dentro, o fuera de su convento, si no es en el tono del instituto recoleto..."; ver Archivo Franciscano de Santiago, Actas del definitorio, vol. 1 (1662-1692), fol. 254.

109 Araya 1999: 37, cita otra muestra de ello: un bando de 1766 ordena que sean expulsados de la villa de Copiapó "los que cantasen pallas y palabras sucias".

110 Alruiz y Fahrenkrog 2008: 54. 
Como es sabido, el órgano era un instrumento fundamental en la iglesia católica y el Chile colonial no era la excepción. Prueba de ello es que en el acta de erección de la catedral de Santiago el único oficio musical que se declara, aparte del chantre, es el de organista, ${ }^{111}$ a quien correspondía acompañar tanto el canto llano como la polifonía. Por tanto, en iglesias más pequeñas, como la de Huaquén, que solo contaba con una guitarra como instrumento acompañante, el guitarrista debió de constituirse en una suerte de organista, que debía asistir de forma regular a las ceremonias eclesiásticas.

Sin embargo, también es sabido que el órgano era un instrumento que requería de una mantención permanente y las iglesias chilenas no siempre estaban en condiciones de proporcionarla. Durante el siglo XVII, los organeros documentados en Santiago eran extranjeros que residieron allí de forma temporal, ${ }^{112}$ lo que explica que, en el documento citado de 1609, el obispo afirmara que los dos órganos de la catedral se hallaban en muy mal estado porque no había quién los pudiese reparar. Incluso, es posible que esta misma razón fuese la que llevó a los mercedarios a enviar transitoriamente a Lima el "órgano pequeño" que tenían en 1683. ${ }^{113}$ Así, cuando su instrumento se hallaba en mal estado, el organista debía proseguir con su labor y por lo general lo hacía interpretando otro instrumento de teclado cuya sonoridad es sorprendentemente parecida a la del guitarrón: el clave o clavecín. ${ }^{114} \mathrm{Su}$ uso en las iglesias santiaguinas ha sido documentado desde $1595,{ }^{115}$ y aún seguía usándose regularmente en el siglo XVIII, cuando la presencia de organeros de nivel parece haber aumentado significativamente en la ciudad. ${ }^{116}$ A modo de ejemplo, la catedral de Santiago compró un clave en 1781;117 el mismo año los agustinos hicieron reparar el que tenían; ${ }^{118}$ y a fines de dicho siglo los franciscanos poseían un órgano y un clave, entre otros instrumentos. ${ }^{119}$ Por ello, la semejanza en cuanto al timbre puede no ser casual. Posiblemente, la adición

111 He consultado la copia tardía conservada en el Archivo Histórico del Arzobispado de Santiago, Gobierno, vol. 7, fol. 9v y siguientes.

112 Me refiero a Baltazar Fernández de los Reyes y Juan Damasceno. Sobre el primero, activo a comienzos del siglo XVII, ver Vera 2004c: 116-117. Sobre el segundo, activo a fines de dicho siglo, ver Alruiz y Fahrenkrog 2008: 50.

113 Vera 2004b: 371.

114 Invito a quien no esté familiarizado con la sonoridad de ambos instrumentos a compararlas en Youtube. Para el guitarrón, recomiendo el video de Francisco Astorga disponible en https://www. youtube.com/watch?v=OwhhGE0aNX8 (consultado el 19 de mayo de 2015).

115 Vera 2004c: 111-112.

116 El organero jesuita Jorge Kranzer vivió en Santiago durante varios años; ver Pereira Salas 1965: 93. También lo hizo durante décadas el organero mercedario Francisco Marieluz, originario de Lima; ver Vera 2011: 178. A fines del siglo XVIII consta la presencia en la ciudad de otro organero llamado Juan de Dios León, de quien no tenemos más datos; ver Vera 2004b: 381. Adicionalmente, el maestro de capilla de la catedral, Francisco Silva, tenía conocimientos de organería, como lo demuestran los 150 pesos que se le pagaron en 1780 por la "compostura del órgano"; ver Archivo de la Catedral de Santiago, Libro general de cuentas, años 1779 y siguientes, 22v.

117 Archivo de la Catedral de Santiago, Libro general de cuentas, años 1779 y siguientes, fol. 39.

118 Archivo Agustino de Santiago, "Libro de gastos que hizo y comenzó el M. R. P. Maestro Procurador fr. Pedro Gamboa, desde el día 22 de septiembre de 1780", fol. 31.

119 Vera 2004c: 115. 
de cuerdas metálicas o "de alambre" al guitarrón tuvo como objetivo asemejarlo al instrumento que, junto al órgano, debía acompañar regularmente la música sacra.

Finalmente, otro instrumento importante en las iglesias coloniales era el arpa. En 1781 las cuentas de los agustinos de Santiago registran pagos a un arpista; ${ }^{120}$ en 1783 se reparó un arpa perteneciente a los mercedarios; ${ }^{121}$ el convento agustino de Quillota tenía en 1784 "un arpa para tocar en la iglesia”, ${ }^{122}$ y en 1785 las cuentas del convento de La Merced de San Felipe mencionan a un arpista, así como gastos realizados en encordar el arpa. ${ }^{123}$ Así, y aunque la sonoridad en este caso sea quizás menos similar, el incremento del número de cuerdas del guitarrón podría relacionarse con dicho instrumento.

Considerando todo lo anterior, mi hipótesis es que el guitarrón chileno constituye una variante local de la guitarra de cinco órdenes, destinada a incorporar en ella algunas de las características de los instrumentos eclesiásticos por excelencia en la época, especialmente el órgano y el clave, con los cuales comparte la amplitud y variedad de registros, las octavas y dobles octavas y, en general, la variedad tímbrica ya observada. Inclusive, registros agudos del órgano como el de pajaritos podrían relacionarse con el uso de los “diablitos" laterales ya mencionados. Esta variante debió de gestarse en el Chile colonial, muy posiblemente en Santiago, debido a las once "guitarras grandes" encontradas en inventarios del siglo XVIII y el grado de dispersión del instrumento, si bien, con la evidencia actual, tampoco puede descartarse que fuese en las zonas rurales del valle central.

La procedencia eclesiástica del guitarrón se ve apoyada además por dos rasgos de la práctica actual de ejecución. Primero, los rasgueos prácticamente se omiten, a pesar de que sus intérpretes conocen la amplia gama de rasgueos de la guitarra campesina. ${ }^{124}$ Esto podría deberse a que, como hemos visto en la sección anterior, durante los siglos XVII y XVIII los rasgueos estridentes eran vinculados con un modo popular de ejecución, mientras que el estilo punteado y los rasgueos más delicados (ejecutados solo con algunos dedos de la mano derecha) representaban los valores de la cultura oficial, lo que pudo hacer que fuesen considerados más idóneos para acompañar la música litúrgica. Segundo, la ejecución del guitarrón es predominantemente masculina, ${ }^{125}$ hecho que podría relacionarse con el papel limitado que la mujer tenía como intérprete musical en las iglesias, como muestran diversos documentos emitidos por la autoridad eclesiástica de Santiago en el siglo XIX. ${ }^{126}$ Finalmente, otra característica del canto a lo divino que podría indicar una procedencia eclesiástica, es el respeto que muestran los cantores a

120 Archivo Agustino de Santiago, "Libro de gastos...", fol. 23.

121 Vera 2004b: 374.

122 Archivo Agustino de Santiago, "Visita y reforma de esta provincia de Chile", año 1784, fol. 38.

123 Archivo Mercedario de Santiago, Libro de gastos del "Convento formado en la villa de Aconcagua”, años 1784-1803, fols. 1-23.

124 Pérez de Arce 2007: 29.

125 Lenz 1919: 521; Pérez de Arce 2007: 36-37; y Pinkerton 2007: 205-206.

126 El canto femenino en la iglesia es severamente restringido en el edicto emitido por el arzobispo Valdivieso en 1873 y en la "Pastoral colectiva sobre la música i canto", de 1885; ver Vera y Cabrera 2011: 770-771. Cf. Salinas 2000: 48-49, 55, 57. 
los textos tradicionales. Por lo general, en las vigilias y otros rituales se espera que un cantor nuevo se dedique inicialmente a escuchar y aprender de los cantores más experimentados. Una vez que se le permite cantar, se espera que recurra a textos aprendidos de sus maestros, antes que a improvisar textos propios respecto del fundamento o tema en cuestión, como podría ocurrir en el marco del canto a lo humano; ${ }^{127}$ costumbres que podrían relacionarse con el respeto a los textos oficiales que debía observarse en las iglesias durante la celebración del culto.

\section{CONCLUSIONES}

Son varias las conclusiones que podemos extraer de estas páginas, así como nuevas preguntas que pueden alimentar futuras investigaciones.

Primero, resulta claro que la guitarra y los instrumentos afines a ella fueron profusamente empleados en el Chile colonial, pues si bien la documentación analizada procede del fondo Escribanos de Santiago, documentos complementarios muestran su uso en otras ciudades y pueblos. Durante el siglo XVII parece haber sido un instrumento transversal a los diferentes sectores sociales e instituciones. No obstante, en el siglo XVIII la elite parece haberse distanciado progresivamente de ella, especialmente tratándose de la guitarra "barroca" o de cinco órdenes. Esto queda de manifiesto en las instituciones religiosas, ya que en el siglo XVII la guitarra figura en los conventos santiaguinos, pero en el siglo XVIII la encontramos más bien en iglesias de otras ciudades y pueblos. Así, en 1802 la "guitarrita" -término que posiblemente aluda a la guitarra de cinco órdenes- sería desterrada del convento franciscano de Santa Rosa de Curimón por considerarse "indecente".

Segundo, y como ya han afirmado otros autores, el guitarrón puede considerarse una variante local de la guitarra barroca. $\mathrm{Al}$ igual que ella, es un instrumento de cinco órdenes, aunque lleve añadidos los "diablitos". Además, tanto la terminología empleada tradicionalmente por los guitarroneros ("bordones", "alambre", etc.) como algunas técnicas de ejecución (apoyo del meñique sobre o cerca del puente; uso de los dedos pulgar, índice y medio de la mano derecha) sugieren una raigambre colonial. Incluso, es posible que algunas de las "guitarras grandes" encontradas en Santiago durante el siglo XVIII correspondan a este instrumento, aunque lo escueto de las descripciones haga imposible saberlo a ciencia cierta.

Tercero, el canto a lo divino, una de las manifestaciones más propias de dicho instrumento, presenta semejanzas musicales con las entonaciones salmódicas de los siglos XVII y XVIII. "La dentradora", por ejemplo, se asemeja a la antigua entonación del octavo tono y otras entonaciones muestran similitudes quizás menos marcadas, pero significativas. Al mismo tiempo, la evidencia documental sugiere que la guitarra como instrumento y las entonaciones salmódicas como tipo de canto predominaban en las iglesias coloniales. De modo que, muy posiblemente, el canto a lo divino deriva de la práctica común de "entonar" los diversos textos

127 Entrevista a Francisco Astorga, realizada el 5 de enero de 2015 en la Universidad Metropolitana de Ciencias de la Educación (UMCE), de Santiago. 
litúrgicos con acompañamiento de guitarra o guitarrón, una práctica que, en torno a 1800, si no antes, comenzó a ser erradicada de los templos a medida que la elite se volvía menos tolerante con el instrumento, para quedar finalmente recluida a las casas particulares y ceremonias privadas.

Cuarto, en caso de ser cierta la hipótesis anterior, la variedad tímbrica del guitarrón no provendría tanto de la música de los pueblos indígenas del Chile central, como ha propuesto Pérez de Arce, sino más bien de la necesidad de reemplazar a los instrumentos usados con mayor frecuencia para acompañar el canto en la iglesia, especialmente el órgano y el clave, ambos a cargo del organista (principal instrumentista en el ámbito eclesiástico). Así, la antigua guitarra de cinco órdenes habría incorporado algunas de las características de dichos instrumentos, como, por ejemplo, el incremento de su sonoridad, la variedad de registros, el empleo de octavas y dobles octavas en un mismo orden y-en el caso del clave- las cuerdas metálicas o de "alambre".

Esto último, empero, no implica afirmar que el instrumento tiene una raigambre exclusivamente española o europea. Por el contrario, de ser cierta esta hipótesis, el guitarrón constituiría una refinada e ingeniosa variante de la guitarra de cinco órdenes que incorpora propiedades de otros instrumentos muy distintos a ella. Pero dicha variante sería local, no española ni europea, por ello el instrumento denotaría un mestizaje o sincretismo, en el sentido de combinar las características típicas de la guitarra barroca con las innovaciones de los constructores chilenos -esto, sin descartar los rasgos mestizos o sincréticos que pudieran hallarse en las ornamentaciones de su caja de resonancia o en su uso ritual, entre otros aspectos-.

En el mismo sentido, mi propuesta de reconstrucción histórica no implica cerrar la puerta a la identidad múltiple que el instrumento ha llegado a adquirir en nuestros días, a ese "espacio simbólico abierto" del que habla Pinkerton en su tesis. ${ }^{128}$ Esto se relaciona con el concepto de origen, que ha constituido un foco de interés para este trabajo. Es verdad que el término ha pasado en las últimas décadas de ser un tópico central a uno muy poco explorado por la historiografía de la música, pero esto se debe no al concepto en sí mismo, sino a los postulados esencialistas a los que con frecuencia dio lugar. Así, y como afirma Leo Treitler, no se trata de que el origen no constituya un objeto de interés para la musicología actual; la diferencia es que ahora no representa la cualidad esencial de una práctica u objeto determinado. ${ }^{129}$ En consecuencia, el plantear que el guitarrón y el canto a lo divino se originaron, en algunos de sus aspectos, en el marco de la música litúrgica de las iglesias coloniales, de ningún modo significa que dicho contexto y función sean los únicos válidos, por encima de otros que se han dado posteriormente.

Más allá del tema específico tratado aquí, los resultados permiten plantear algunas propuestas que pudieran resultar útiles para otros trabajos. Hemos visto

128 Pinkerton 2007: viii, 11.

129 Treitler 1989: 168. 
que la entonación conocida como "La dentradora" y otras del canto a lo divino actual parecen conservar de las antiguas entonaciones salmódicas solo algunos de sus giros melódicos característicos. A mi juicio, esto sugiere que, con frecuencia, lo que se conserva en la tradición oral no es la estructura musical intrínseca, como podría pensarse desde un punto de vista schenkeriano, sino tan solo algunos "gestos" que, según la terminología acuñada por Robert Hatten, se hallan "marcados" en las músicas que han influido en dicha tradición.130

Otro punto tiene que ver con la escritura y la oralidad. Por un lado, el canto a lo divino podría considerarse como una práctica de tradición oral. Sin embargo, sus textos son en parte de tradición escrita, ya que los "fundamentos" proceden de la Biblia; además, hay indicios de que a comienzos del siglo XX algunos cantores de las zonas rurales adquirieron los versos editados en la llamada Lira popular, para luego incorporarlas a su acervo. ${ }^{131}$ Por otro lado, podríamos pensar en las entonaciones salmódicas como una práctica de tradición escrita, por cuanto figuran virtualmente inalteradas en los tratados de los siglos XVI a XVIII. Sin embargo, hemos visto que Cerone concebía su uso para cantar "sin libro puntado" y otro teórico, Nassarre, afirmaba haberse sentido obligado a transcribirlas porque "ordinariamente se introducen abusos en lo que nunca se ve escrito..."; 132 es decir, la práctica diaria incorporaba alteraciones que no quedaban reflejadas en los libros. Este importante componente de oralidad se ve confirmado por otro rasgo que, según han demostrado los etnomusicólogos, caracteriza a algunas músicas de tradición oral, especialmente cuando cumplen una función ritual: el hecho de que diferenciaciones sonoras que parecen muy pequeñas para alguien ajeno a la cultura que las produce, pueden constituirse en rasgos marcadamente distintivos o identitarios. ${ }^{133}$ Esta misma característica se aprecia en las antiguas entonaciones, como lo demuestra el modo de entonar la invocación inicial de los maitines en las catedrales y en los conventos de religiosos, según el tratado de Nassarre. Las diferencias (ver ejemplo 9) podrán parecer mínimas para nosotros, pero eran suficientes en la época para distinguir a las órdenes religiosas del clero secular. ${ }^{134}$

130 Cf. Hatten 2004: 1-18.

131 Mendoza 2009: 45. El testimonio citado es del cantor Alfonso Rubio.

132 Nassarre 1724: 180.

133 Xavier Bellenger, por ejemplo, señala en el prólogo de su libro acerca de la música andina que uno de los aspectos que más le llamó la atención al inicio de sus investigaciones era la tendencia de los músicos locales a interpretar secuencias de músicas prácticamente idénticas. Al ser preguntados por la diferencia entre una música y la precedente, los músicos de Totorani respondían "es lo mismo pero es otra". Posteriormente, Bellenger concluyó que esto se debía a que "cada pieza musical sobreentiende implícitamente al conjunto de la secuencia y, recíprocamente, la secuencia engloba al conjunto de estas mismas piezas"; además, cada secuencia está vinculada a un ritual específico, actuando estas diferencias melódicas y rítmicas (sutiles para nosotros) como marcadores de los diferentes momentos del ritual; ver Bellenger 2007: 37, 42-43, 64, 71.

134 Nassarre 1724: 179. 


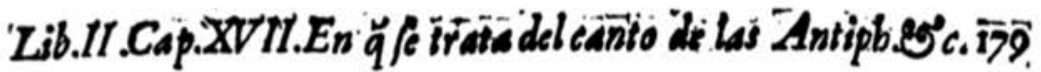

Religiones. El eftilo que tioneo las Cachedrales de entonarlo es todo por la cuerda del fa de cefolfaut, hafta la pepultima filaba, que baxa al mi, donde fe, deciene tiempo doblado, y buelve al fa, con la ultima filaba, refpondiendo al. Coro del milmo modo, como fe puede yèr en efta apuntacion.

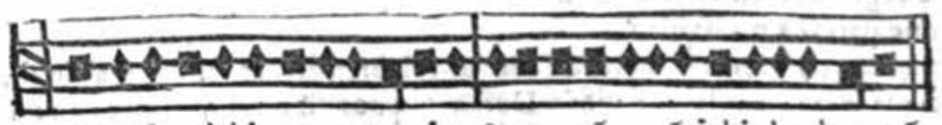

Domine labia mea aperies: \& os meú andútiabic laudem cuá.

El otro modo, que es el que fe eftila en las Religiones de ordinario, fe entona baxando al mi, tres filabas antes, de donde paffa al re, y bolviendo con la penultima filaba al mi, concluye con la ultima en el $f_{A}$, refpondiendo el Core. del milmo modo, y es como fe figue.

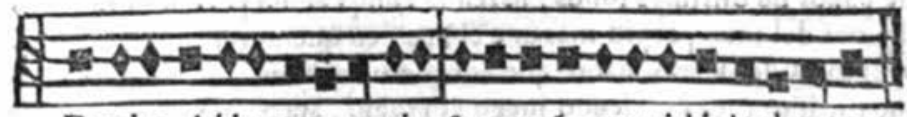

Domine labia mea aperies: \& os meú annuntiabit laudem tuam.

Ejemplo 9

Así, el caso del guitarrón y el canto a lo divino parece confirmar algo que ya habían apuntado otros autores: ${ }^{135}$ que las tradiciones musicales raramente son puramente orales o escritas; más bien confluyen en ellas la escritura y la oralidad en diversos grados. Esta constatación explica y a la vez justifica que en este trabajo se hayan puesto a dialogar la evidencia histórica pasada y las prácticas tradicionales presentes, en un intento por establecer vínculos concretos entre ambas.

Finalmente, si bien la hipótesis presentada aquí podría ayudar a comprender algunas de las características actuales del guitarrón y la práctica del canto a lo divino, no las explica todas (ni ha sido este su propósito). Primero, porque la evidencia reunida, si bien es significativa, resulta todavía insuficiente para ir más allá de un nivel hipotético; y segundo porque, aunque estuviésemos en lo cierto, siguen siendo muchos los aspectos no aclarados. ¿De dónde proviene la predominancia de la décima como forma poética?; ¿en qué medida el castellano estuvo presente en los textos que se entonaban en las iglesias coloniales?; ¿cómo puede comprenderse la abrumadora predominancia del modo mayor en las entonaciones del canto a lo divino, cuando, desde un punto de vista actual, es el modo menor el que predomina en las entonaciones salmódicas del período colonial? Y a pesar de que la evidencia pareciera inclinarse en ese sentido, ¿`se originó efectivamente el guitarrón en Santiago, para ser posteriormente llevado a las iglesias de los pueblos y haciendas, o lo hizo en el ámbito rural? Estas y otras preguntas han quedado 
abiertas en este trabajo, a la espera de que puedan servir de aliciente para futuros estudios respecto de este y otros temas relacionados.

\section{TABLA 1}

\section{GUITARRAS E INSTRUMENTOS AFINES EN MANOS DE PARTICULARES, LOCALIZADOS EN EL FONDO ESCRIBANOS DE SANTIAGO ${ }^{136}$.}

Las referencias se ordenan en forma alfabética, de acuerdo con el nombre de los instrumentos, además de cronológica en caso de existir más de una referencia por instrumento.

\begin{tabular}{|c|c|c|c|c|}
\hline $\begin{array}{l}\text { Instrumento } \\
\text { (y cantidad si hay } \\
\text { más de uno) }\end{array}$ & Año & Propietario(s) & $\begin{array}{c}\text { Fuente en Archivo } \\
\text { Nacional Histórico, } \\
\text { Fondo Escribanos } \\
\text { de Santiago }\end{array}$ & Observaciones \\
\hline Bandola & 1791 & $\begin{array}{c}\text { Puente, Celedonio } \\
\text { de la }\end{array}$ & Vol. 854, fol. 182 & \\
\hline Bandurria & 1791 & Núñez, Eugenio & Vol. 854, fol. 25 & $\begin{array}{l}\text { Tenía además dos guitarras } \\
\text { de seis órdenes (ver infra). } \\
\text { Tras la almoneda o remate } \\
\text { la adquirió don Manuel de } \\
\text { Quevedo. }\end{array}$ \\
\hline Cítara & 1642 & Griego, Juan & $\begin{array}{l}\text { Vol. } 170 \text {, fol. } 235 \text { y } \\
\text { vol. } 190 \text {, fol. } 305\end{array}$ & El original dice "sítora". \\
\hline Discante & 1600 & $\begin{array}{l}\text { Alvarado, } \\
\text { Catalina de }\end{array}$ & Vol. 26 , fol. $120 \mathrm{v}$ & Citado por Pinto 2009. \\
\hline Discante (2) & 1620 & $\begin{array}{l}\text { Balcázar, } \\
\text { Garcilaso de }\end{array}$ & Vol. 80 , fol. $275 \mathrm{v}$ & $\begin{array}{c}\text { En su testamento los dejó } \\
\text { al convento de monjas } \\
\text { agustinas. Uno de ellos era } \\
\text { un discante "pequeñito o } \\
\text { menor". Tenía además una } \\
\text { vihuela (ver infra). }\end{array}$ \\
\hline Discante (5) & 1635 & $\begin{array}{c}\text { Pinto de Escobar, } \\
\text { Blas }\end{array}$ & Vol. 100 , fol. $363 \mathrm{v}$ & $\begin{array}{c}\text { Los discantes eran "de } \\
\text { Lima" y estaban en su } \\
\text { tienda, seguramente para ser } \\
\text { vendidos. }\end{array}$ \\
\hline Discante grande & 1665 & $\begin{array}{c}\text { Mejía de Guevara, } \\
\text { Josefa }\end{array}$ & Vol. 309, fol. 105 & \\
\hline Guitarra & 1657 & Machado, Andrés & Vol. 240 , fol. 474 & $\begin{array}{l}\text { La guitarra era "hecha en } \\
\text { Lima". El propietario era } \\
\text { "indio cuzco", de profesión } \\
\text { zapatero y tenía además un } \\
\text { "ravelito" y una "corneta de } \\
\text { tocar en las iglesias". }\end{array}$ \\
\hline Guitarra & 1680 & $\begin{array}{l}\text { Pérez de Riobo, } \\
\text { Domingo }\end{array}$ & Vol. 351, fol. $617 \mathrm{v}$ & $\begin{array}{c}\text { Tenía también } \\
\text { "bordones de arpa". }\end{array}$ \\
\hline
\end{tabular}

136 Con la excepción de la referencia a Guitarra, 1805, que corresponde al Fondo Notarios de Santiago. 


\begin{tabular}{|c|c|c|c|c|}
\hline $\begin{array}{l}\text { Instrumento } \\
\text { (y cantidad si hay } \\
\text { más de uno) }\end{array}$ & Año & Propietario(s) & $\begin{array}{c}\text { Fuente en Archivo } \\
\text { Nacional Histórico, } \\
\text { Fondo Escribanos } \\
\text { de Santiago }\end{array}$ & Observaciones \\
\hline Guitarra & 1691 & $\begin{array}{l}\text { Velasco, Josefa; } \\
\text { Lepe, Joseph de }\end{array}$ & Vol. 375 , fol. $61 \mathrm{v}$ & $\begin{array}{c}\text { Tenía también una vihuela y } \\
\text { un arpa. }\end{array}$ \\
\hline Guitarra & $1698 ; 1699$ & $\begin{array}{c}\text { Vergara, } \\
\text { Francisca de }\end{array}$ & $\begin{array}{l}\text { Vol. } 428 \text {, fol. } 89 \text { y } \\
\text { vol. } 387 \text {, fol. } 466 \text {, } \\
\text { respectivamente }\end{array}$ & \\
\hline Guitarra & 1711 & Márquez, María & Vol. 470 , fol. $236 \mathrm{v}$ & Tenía además un arpa. \\
\hline Guitarra & 1712 & $\begin{array}{c}\text { Añasco, } \\
\text { Francisca de }\end{array}$ & Vol. 953, fol. 299v & $\begin{array}{l}\text { La guitarra era de ébano. } \\
\text { Había además un arpa sin } \\
\text { cuerdas. }\end{array}$ \\
\hline Guitarra & 1714 & $\begin{array}{c}\text { San Paul, Francisco } \\
\text { Antonio de }\end{array}$ & Vol. 505 , fol. 298 & Tenía además un violín. \\
\hline Guitarra & 1717 & $\begin{array}{l}\text { Solís, María Josefa; } \\
\text { Cañedo, Diego }^{137}\end{array}$ & Vol. 509, fol. 22 & Tenía además un arpa. \\
\hline Guitarra & 1718 & $\begin{array}{c}\text { Maldonado, María } \\
\text { Antonia; Ruiz de } \\
\text { Gamboa, Francisco }\end{array}$ & Vol. 510 , fol. 55 & \\
\hline Guitarra & 1720 & $\begin{array}{c}\text { Ojeda, María de; } \\
\text { Fernando de los } \\
\text { Reyes }\end{array}$ & Vol. 513, fol. 13v & Tenía además un arpa. \\
\hline Guitarra & 1731 & $\begin{array}{c}\text { Fontecilla y Villela, } \\
\text { Juana; Araus, Juan } \\
\text { Antonio }\end{array}$ & Vol. 630, fol. 112 & \\
\hline Guitarra & $1734 ; 1735$ & $\begin{array}{l}\text { Cerda, Juan } \\
\text { de Dios de la }\end{array}$ & $\begin{array}{l}\text { Vol. 537, fol. 226v; y vol. } \\
538 \text {, fol. } 208 \mathrm{v}\end{array}$ & $\begin{array}{l}\text { Tenía también un arpa. } \\
\text { El segundo documento } \\
\text { corresponde a la partición, } \\
\text { fechada en } 9 \text { de marzo } \\
\text { de } 1735 \text {. La guitarra fue } \\
\text { adjudicada ahí a María de la } \\
\text { Cerda, una de sus hijas. }\end{array}$ \\
\hline Guitarra & 1741 & $\begin{array}{l}\text { Meneses, María } \\
\text { Josefa de }\end{array}$ & Vol. 653 , fol. $31 \mathrm{v}$ & $\begin{array}{l}\text { Era un instrumento lujoso, } \\
\text { pues se describe como "una } \\
\text { guitarra de madera negra } \\
\text { embutida en marfil con una } \\
\text { cinta de tela azul con su caja } \\
\text { de tabla de Alerce con llave". }\end{array}$ \\
\hline Guitarra & 1745 & Leiva, Pablo & Vol. 637, fol. 296 & \\
\hline Guitarra & 1756 & $\begin{array}{c}\text { Timón, Rosa; Frías } \\
\text { y Ríos, Joseph }\end{array}$ & Vol. 735 , fol. 248 & \\
\hline Guitarra & 1774 & Hurtado, Ignacio & $\begin{array}{l}\text { Vol. } 719 \text {, fol. } 404 \text { y vol. } \\
883 \text {, fols. } 5 \text { lv y } 178\end{array}$ & $\begin{array}{c}\text { Tenía además un arpa, "algo } \\
\text { vieja, rompida }[s i c] \text { por } \\
\text { debajo". }\end{array}$ \\
\hline
\end{tabular}

137 En el caso de las dotes, indico el nombre tanto de la mujer como del marido, por tratarse de bienes que eran aportados por la familia de la cónyuge al matrimonio en su conjunto. 


\begin{tabular}{|c|c|c|c|c|}
\hline $\begin{array}{l}\text { Instrumento } \\
\text { (y cantidad si hay } \\
\text { más de uno) }\end{array}$ & Año & Propietario(s) & $\begin{array}{l}\text { Fuente en Archivo } \\
\text { Nacional Histórico, } \\
\text { Fondo Escribanos } \\
\text { de Santiago }\end{array}$ & Observaciones \\
\hline Guitarra & 1805 & Rodríguez, Juan & $\begin{array}{c}\text { Fondo Notarios de } \\
\text { Santiago, vol. 4, fol. 305v }\end{array}$ & \\
\hline Guitarra (2) & 1703 & Ugarte, Juan de & $\begin{array}{c}\text { Fondo Escribanos de } \\
\text { Santiago, Vol. } 440, \\
\text { fol. } 299\end{array}$ & $\begin{array}{l}\text { El propietario era } \\
\text { "comisario general". Tenía } \\
\text { además "un arpa grande". }\end{array}$ \\
\hline Guitarra (2) & 1712 & $\begin{array}{l}\text { Aulestia, Josepha } \\
\text { Leonarda de; } \\
\text { Román de } \\
\text { Aulestia, Joseph } \\
\text { Toribio }\end{array}$ & Vol. 503, fol. 48 & \\
\hline Guitarra (2) & 1713 & Varas, Gaspar & Vol. 504, fol. 264 & $\begin{array}{c}\text { Una de las guitarras estaba } \\
\text { "quebrada". }\end{array}$ \\
\hline Guitarra (2) & 1748 & $\begin{array}{l}\text { Brazena, } \\
\text { Bernardo de la }\end{array}$ & Vol. 599 , fol. $12 \mathrm{v}$ & \\
\hline Guitarra (2) & 1777 & $\begin{array}{c}\text { Bezanilla, Manuel } \\
\text { de }\end{array}$ & Vol. 820 , fol. $335 \mathrm{v}$ & \\
\hline Guitarra de China & 1718 & $\begin{array}{l}\text { Rojas, Mariana } \\
\text { de; Pérez de } \\
\text { Valenzuela, } \\
\text { Lorenzo }\end{array}$ & Vol. 610 , fol. $4 \mathrm{v}$ & \\
\hline $\begin{array}{c}\text { Guitarra de China } \\
\text { colorada }\end{array}$ & $1723 ; 1726$ & $\begin{array}{l}\text { Solar, María } \\
\text { Josefa del }\end{array}$ & $\begin{array}{l}\text { Vol. } 522 \text {, fol. } 237 \text { y vol. } \\
643 \text {, fol. } 55\end{array}$ & \\
\hline $\begin{array}{l}\text { Guitarra de seis } \\
\text { órdenes (2) }\end{array}$ & 1791 & Núñez, Eugenio & Vol. 854 , fol. 25 & $\begin{array}{l}\text { Una de las guitarras era } \\
\text { "de madera de pino la una } \\
\text { enbutida [sic] en concha de } \\
\text { perla". Tenía además una } \\
\text { bandurria (ver supra). } \\
\text { En el remate o "almoneda" } \\
\text { de estos bienes, una de las } \\
\text { guitarras (la más cara, en } \\
9 \text { pesos) se designa como } \\
\text { "vihuela". } \\
\text { Ambas fueron adquiridas } \\
\text { por don Manuel de } \\
\text { Quevedo. }\end{array}$ \\
\hline Guitarra grande & 1701 & $\begin{array}{c}\text { Díaz de Herrera, } \\
\text { Josefa; Bara, } \\
\text { Andrés de }\end{array}$ & Vol. 387, fol. 402 & Tenía también un arpa. \\
\hline Guitarra grande & 1711 & $\begin{array}{c}\text { Jofré, Manuela; } \\
\text { Vargas, Pedro }\end{array}$ & Vol. 580 , fol. $91 \mathrm{v}$ & \\
\hline Guitarra grande & 1715 & $\begin{array}{c}\text { Alvarado, Beatriz } \\
\text { de; Marful, } \\
\text { Joseph }\end{array}$ & Vol. 507 , fol. $307 \mathrm{v}$ & \\
\hline Guitarra grande & 1715 & Quevedo, Ana de & Vol. 584, fol. $96 \mathrm{v}$ & \\
\hline
\end{tabular}




\begin{tabular}{|c|c|c|c|c|}
\hline $\begin{array}{l}\text { Instrumento } \\
\text { (y cantidad si hay } \\
\text { más de uno) }\end{array}$ & Año & Propietario(s) & $\begin{array}{c}\text { Fuente en Archivo } \\
\text { Nacional Histórico, } \\
\text { Fondo Escribanos } \\
\text { de Santiago }\end{array}$ & Observaciones \\
\hline Guitarra grande & 1751 & $\begin{array}{l}\text { Salinas y Vera, } \\
\text { Rosa; Quezada, } \\
\text { Fermín de }\end{array}$ & Vol. 690 , fol. $224 \mathrm{v}$ & $\begin{array}{c}\text { La guitarra era "de Lima". } \\
\text { Había además dos "arpas } \\
\text { nuevas". }\end{array}$ \\
\hline Guitarra grande & 1752 & $\begin{array}{c}\text { Loaisa, Bartolina; } \\
\text { Orórtegui, } \\
\text { Ventura de }\end{array}$ & Vol. 600 , fol. $198 \mathrm{v}$ & $\begin{array}{c}\text { Había además un "arpa } \\
\text { nueva con dos llaves la una } \\
\text { de plata y la otra de hierro". }\end{array}$ \\
\hline Guitarra grande & 1763 & Regoy, Ambrosio & Vol. 772 , fol. $14 \mathrm{v}$ & \\
\hline Guitarra grande & 1775 & $\begin{array}{l}\text { Ugarte, Joseph } \\
\text { Baltasar de }\end{array}$ & Vol. 784, fol. 166 & $\begin{array}{l}\text { Un sujeto llamado "Joseph } \\
\text { de Ugarte" tenía un clave } \\
\text { en } 1772 \text { (vol. } 715 \text {, fol. } \\
\text { 194). Pudo ser él mismo, o } \\
\text { quizás su hermano Joseph } \\
\text { Antonio. }\end{array}$ \\
\hline Guitarra grande & 1793 & Flores, Gaspar & Vol. 856, fol. 195 & \\
\hline Guitarra grande (2) & 1723 & $\begin{array}{l}\text { Eyzaguirre, } \\
\text { Francisco de }\end{array}$ & Vol. 519 , fol. $49 \mathrm{v}$ & \\
\hline Guitarra mediana & 1676 & $\begin{array}{c}\text { Carreto, Mariana; } \\
\text { Vargas, Bernabé } \\
\text { de }\end{array}$ & Vol. 322, fol. 14 & Había además un arpa. \\
\hline Guitarra pequeña & 1658 & $\begin{array}{l}\text { Carrasco, } \\
\text { Bartolomé }\end{array}$ & Vol. 145, fol. 211 & $\begin{array}{l}\text { La expresión "guitarra } \\
\text { pequeña" probablemente } \\
\text { equivale a un discante. }\end{array}$ \\
\hline Vihuela & 1587 & $\begin{array}{l}\text { Bermúdez, } \\
\text { Jerónimo }\end{array}$ & Vol. 3, fol. 396v & $\begin{array}{l}\text { Al parecer el instrumento } \\
\text { se hallaba empeñado en } \\
\text { manos del mulato Antón de } \\
\text { Guzmán. También lo cita } \\
\text { De Ramón 2006: } 72 .\end{array}$ \\
\hline Vihuela & 1605 & $\begin{array}{l}\text { Saucedo, } \\
\text { Francisco de }\end{array}$ & Vol. 35bis, fol. 159 & $\begin{array}{l}\text { El instrumento se hallaba } \\
\text { empeñado en manos del } \\
\text { padre Joan Cano de Araya. }\end{array}$ \\
\hline Vihuela & 1620 & $\begin{array}{c}\text { Balcázar, } \\
\text { Garcilaso de }\end{array}$ & Vol. 80, fol. 275v & $\begin{array}{c}\text { Tenía además dos discantes } \\
\text { (ver supra). }\end{array}$ \\
\hline Vihuela & 1665 & Oses, Juana de & Vol. 264, fol. 28 & $\begin{array}{l}\text { Luego de morir la } \\
\text { propietaria, se vendió “al } \\
\text { tesorero don Francisco } \\
\text { Ramírez”. }\end{array}$ \\
\hline Vihuela & 1679 & Millán, Francisco & Vol. 350, fol. 189 & \\
\hline Vihuela & 1691 & $\begin{array}{l}\text { Velasco, Josefa; } \\
\text { Lepe, Joseph de }\end{array}$ & Vol. 375 , fol. $61 \mathrm{v}$ & $\begin{array}{c}\text { Tenía también una guitarra } \\
\text { y un arpa. }\end{array}$ \\
\hline Vihuela & 1698 & $\begin{array}{l}\text { Ovalle y Zapata, } \\
\text { Isabel; Rojas, } \\
\text { Joseph de }\end{array}$ & Vol. 383, fol. 1v & Tenía también un arpa. \\
\hline Vihuela & 1700 & $\begin{array}{l}\text { Maldonado, } \\
\text { Pedro }\end{array}$ & Vol. 386, fol. 203 & \\
\hline
\end{tabular}




\begin{tabular}{|c|c|c|c|c|}
\hline $\begin{array}{l}\text { Instrumento } \\
\text { (y cantidad si hay } \\
\text { más de uno) }\end{array}$ & Año & Propietario(s) & $\begin{array}{c}\text { Fuente en Archivo } \\
\text { Nacional Histórico, } \\
\text { Fondo Escribanos } \\
\text { de Santiago }\end{array}$ & Observaciones \\
\hline Vihuela & 1702 & $\begin{array}{c}\text { Quiroz, Francisco } \\
\text { Bernardo }\end{array}$ & Vol. 438 , fol. $30 \mathrm{v}$ & \\
\hline Vihuela & 1710 & \begin{tabular}{|c|} 
Bracamonte, \\
María Eugenia; \\
Campo Lantadilla, \\
Bartolomé del
\end{tabular} & Vol. 953, fol. 104. & \\
\hline Vihuela & 1723 & Santana, Joseph & Vol. 625 , fol. 155 & \\
\hline Vihuela & 1731 & $\begin{array}{c}\text { Ríos, María Josefa } \\
\text { de los }\end{array}$ & Vol. 495 , fol. $183 \mathrm{v}$ & $\begin{array}{l}\text { La vihuela era "de } \\
\text { jacarandá". }\end{array}$ \\
\hline Vihuela & 1768 & $\begin{array}{c}\text { Errázuriz, Francisco } \\
\text { Javier }\end{array}$ & Vol. 777 , fol. 76 & $\begin{array}{c}\text { Tenía además un clave y dos } \\
\text { violines. } \\
\text { La vihuela tenía "embutidos } \\
\text { de concha de perla" pero } \\
\text { estaba "maltratada". } \\
\text { También menciona estos } \\
\text { instrumentos Pereira Salas } \\
\text { 1941: 42, citando un artículo } \\
\text { de Fernando Márquez de } \\
\text { la Plata, que no he podido } \\
\text { consultar. }\end{array}$ \\
\hline
\end{tabular}

\section{BIBLIOGRAFÍA}

Alruiz, Constanza y LaUra Fahrenkrog

2008 "Construcción de instrumentos musicales en el Virreinato del Perú: vínculos y proyecciones con Santiago de Chile”. Resonancias, № 22 (mayo), pp. 43-62.

Araya, Alejandra

1999 Ociosos, vagabundos y malentretenidos en el Chile colonial. Santiago de Chile: DIBAM [Dirección de Bibliotecas, Archivos y Museos], Centro de Investigaciones Diego Barros Arana.

BaAde, Colleen Ruth

2002 Music and Music-Making in Female Monasteries in Seventeenth-Century Castile (Spain). Tesis para la obtención del grado de Doctor. Durham, Estados Unidos: Duke University. Profesor guía: Peter Williams.

BAKER, GEOFFREY

2008 Imposing Harmony. Music and Society in Colonial Cuzco. Durham y Londres: Duke University Press.

BARros, José D'Assunção

2008 El campo de la historia: especialidades y abordajes. Santiago de Chile: Universidad Católica Silva Henríquez.

Barros, Raquel y Manuel Dannemann

1960 "El guitarrón en el Departamento de Puente Alto", Revista Musical Chilena, XIV/74 (noviembre-diciembre), pp. 7-45. 


\section{BELlenger, XaVier}

2007 El espacio musical andino. Modo ritualizado de producción musical en la isla de Taquile y en la región del lago Titicaca. Lima: Instituto Francés de Estudios Andinos.

Bustamante, Juan y Francisco Astorga

1996 Renacer del guitarrón chileno. Rancagua: AGENPOCH [Asociación Gremial Nacional de Trabajadores de la Poesía Popular, Poetas y Payadores de Chile] y FONDART [Fondo Nacional de Desarrollo Cultural y las Artes].

Carrasco, Fr. Bernardo

1691 "Reglas, consuetas, e instituciones consuetudinales de la Iglesia Cathedral de Santiago de Chile, celebradas en 20. de Diziembre año de 1689", en Fr. Bernardo Carrasco. Synodo Diocesana [1688]. Lima: Imprenta de Joseph de Contreras y Alvarado, fols. 56-71.

1764 Synodo Diocesana [1688]. Lima: Imprenta Real.

Cerone, Pietro

1613 El Melopeo y Maestro. Nápoles: Juan Bautista Gargano y Lucrecio Nucci. Corona, Antonio

1995 "The Popular Music From Veracruz and the Survival of Instrumental Practices of the Spanish Baroque", Ars Musica Denver, VII/2 (primavera), pp. 39-68.

Covarrubias Orozco, Sebastián de

1979 Tesoro de la lengua castellana o española [1611]. Madrid: Ediciones Turner.

Dannemann R., Manuel

1974 "Estudios sobre música folklórica chilena", Aisthesis, № 8, pp. 269-305.

De Ramón, Emma

2006 "Artífices negros, mulatos y pardos en Santiago de Chile", Cuadernos de Historia, $\mathrm{N}^{\circ} 25$ (marzo), pp. 59-82.

Díaz Meza, Aurelio

1975 Leyendas y episodios chilenos. Volumen 2. En plena Colonia. Santiago: Nascimento.

Domínguez, Ramón JoAQuín

1853 Diccionario Nacional o Gran Diccionario Clásico de la Lengua Española (1846-47). Madrid-París: Establecimiento de Mellado.

FAHRENKRog, LAURA

2011 "Aproximación a las prácticas musicales populares durante la Colonia (Santiago de Chile, s. XVIII)", Neuma, IV/2, pp. 66-90.

2012 Prácticas musicales populares urbanas durante la Colonia (Santiago de Chile, 1750-1810). Tesis para la obtención del grado de Master en Música Hispana. Salamanca: Universidad de Salamanca. Profesor guía: José Máximo Leza.

Ferretti, Paolo

1938 Esthétique Grégorienne ou Traité des Formes Musicales du Chant Grégorien París, Tournai, Roma: Société de Saint Jean L'Évangéliste, Desclée \& Cie.

Grebe, María Ester

1967a "Modality in Spanish Renaissance Vihuela Music and Archaic Chilean Folksongs: A Comparative Study”, Ethnomusicology, XI/3 (septiembre), pp. 326-342. 
1967b The Chilean Verso: A Study in Musical Archaism. Los Angeles, California: Universidad de California, Latin American Center.

Hatten, Robert S.

2004 Interpreting Musical Gestures, Topics and Tropes. Mozart, Beethoven, Schubert. Bloomington e Indianápolis: Indiana University Press.

JORDÁ, Miguel (EDITOR)

1973 Versos a lo divino y a lo humano. Santiago: Mundo.

KERMAN, JOSEPH

1983 “A Few Canonic Variations”, Critical Inquiry, X/1 (septiembre), pp. 107-125.

LENG, Alfonso

1927 "Sobre el arte musical chileno", Marsyas, I/4 (junio), pp. 117-119.

LENZ, RODOLFO

1919 Sobre la poesía popular impresa de Santiago de Chile. Contribución al folklore chileno. Santiago: Imprenta y Litografía Universo. La paginación proviene de un ejemplar publicado como separata de los Anales de la Universidad de Chile y disponible digitalmente en http://www.memoriachilena.cl/602/w3-article-7746.html (consultado el 29 de abril de 2016).

LEÓN, LEONARDO

2007 "Real Audiencia y bajo pueblo en Santiago de Chile colonial, 1750-1770", en Jaime Valenzuela (editor). Historias urbanas. Homenaje a Armando de Ramón. Santiago de Chile: Ediciones Universidad Católica de Chile, pp. 67-90.

MARín López, JaVier

2007 Música y músicos entre dos mundos: la catedral de México y sus libros de polifonía (siglos XVI-XVIII). Tesis para la obtención del grado de Doctor en Historia y Ciencias de la Música. Granada: Universidad de Granada. Profesor guía: Emilio Ros-Fábregas.

Mendoza, Esteban

2009 Circulación rural-urbana del canto a lo divino en la dinámica del siglo XXI: ¿̨purismo o mutación?’. Tesis para la obtención del grado de Licenciado en Música, mención Musicología. Santiago: Pontificia Universidad Católica de Chile, Instituto de Música. Profesor guía: Rafael Díaz.

Millar, René y Carmen Gloria Duhart

2005 "La vida en los claustros. Monjas y frailes, disciplinas y devociones", en Rafael Sagredo y Cristián Gazmuri (editores). Historia de la vida privada en Chile. Volumen 1. El Chile tradicional. De la conquista a 1840. Santiago: Taurus, pp.125-159.

Muñoz Olave, Reinaldo

1926 Las monjas trinitarias de Concepción. 1570-1822. Relato histórico. Santiago: Imprenta de San José.

Murcia, Santiago de

2010 Cifras selectas de guitarra. Edición crítica de Alejandro Vera. Middleton, Wisconsin: A-R Editions.

NASSARre, Pablo

1724 Escuela música según la práctica moderna. Parte 1. Zaragoza: Herederos de Diego de Larumbe. 
Pereira Salas, Eugenio

1941 Los origenes del arte musical en Chile. Santiago: Publicaciones de la Universidad de Chile, Imprenta Universitaria.

1962 "Nota sobre los orígenes del canto a lo divino en Chile". Revista Musical Chilena XVI/79 (enero-marzo), pp. 41-48.

1965 Historia del arte en el reino de Chile. Santiago: Ediciones de la Universidad de Chile.

Pérez de Arce, José

2007 "El guitarrón chileno y su armonía tímbrica", Resonancias, № 21 (noviembre), pp. 22-55.

Pinkerton, Emily J.

2007 The Chilean Guitarrón: The Social, Political and Gendered Life of a Folk Instrument. Tesis para la obtención del grado de Doctor. Texas, Austin: University of Texas at Austin. Profesor guía: Stephen Slawek.

PinTo, SONIA

2009 "Testamentos coloniales: una fuente para la historia social de Chile", ponencia inédita presentada en las XVIII Jornadas de Historia de Chile. Valdivia: Universidad Austral.

RANCIOSINI FLORENTÍN, LORENZO

1620 Vocabolario español-italiano, ahora nuevamente sacado a luz [...]. Segunda parte. Roma: Iuan Pablo Profilio, a costa de Iuan Ángel Rufineli y Ángel Manni.

Real Academia Española

1726-1899 Diccionario de la lengua castellana. Madrid: Real Academia Española. Disponible en http://ntlle.rae.es/ntlle/SrvltGUILoginNtlle

RoBledo, LuIS

1989 Juan Blas de Castro (ca. 1561-1631). Vida y obra musical. Zaragoza: Institución Fernando el Católico.

2012 "El canto llano en la tratadística de la época de Victoria". Revista de Musicología, XXXV/1, pp. 297-316.

RONDÓN, VíctoR

2009 Jesuitas, música y cultura en el Chile colonial. Tesis para la obtención del grado de Doctor en Historia. Santiago: Pontificia Universidad Católica de Chile. Profesor guía: Claudio Rolle.

Rosal, FRANCISCO DEL

1611 "Origen y etymología de todos los vocablos originales de la Lengua Castellana...", Biblioteca Nacional de España, manuscrito Ms. 6929 (copia del siglo XVIII).

Russell, Craig H.

1981 Santiago de Murcia: Spanish Theorist and Guitarist of the Early Eighteenth Century. Tesis para la obtención del grado de Doctor. Carolina del Norte, Chapel Hill: University of North Carolina at Chapel Hill. Profesor guía: James W. Pruett.

Salinas, Maximiliano

2000 "iToquen flautas y tambores!: una historia social de la música desde las culturas populares en Chile, siglos XVI-XX”, Revista Musical Chilena, LIV/193 (enero-junio), pp. $45-82$. 
SAMSON, JIM

2009 "Music History", en John Paul Edward Harper-Scott y Jim Samson (editores). An Introduction to Music Studies. Cambridge: Cambridge University Press, pp. 8-19.

SANZ, GASPar

1966 Instrucción de música sobre la guitarra española 1674-1697. Edición facsímil con un estudio introductorio de Luis García-Abrines, Zaragoza: Institución Fernando el Católico.

STEVENS, John

1706 A new Spanish and English Dictionary. Collected from the Best Spanish Authors Both Ancient and Modern. Londres: George Sawbridge, 1706.

STOBART, Henry

2009 "World musics", en John Paul Edward Harper-Scott y Jim Samson (editores). An Introduction to Music Studies. Cambridge: Cambridge University Press, pp. 97-118.

Subiabre, Malucha

2006 La música en las fiestas del Santiago de Chile colonial (siglos XVII-XVIII): tres ejemplos para una primera aproximación. Tesis para la obtención del grado de Licenciada en Música, opción Musicología. Santiago: Pontificia Universidad Católica de Chile, Instituto de Música. Profesor guía: Alejandro Vera.

Treitler, Leo

1989 Music and the Historical Imagination. Cambridge, Massachusetts y Londres, Inglaterra: Harvard University Press.

Uribe EcheVARRÍa, JUAN

1962 Cantos a lo divino y a lo humano en Aculeo. Folklore de la Provincia de Santiago. Santiago: Editorial Universitaria S. A.

Uribe Valladares, Cristhian

2004 "La guitarra en los escritos de la historia musical chilena", Revista Musical Chilena, LVIII/202 (julio-diciembre), pp. 26-37.

Vera, Alejandro

2004a "La música en el convento de La Merced de Santiago de Chile en la época colonial (s. XVII-XVIII)”, Revista Musical Chilena, LVIII/201 (enero-junio), pp. 34-52.

2004b "Music in the Monastery of La Merced, Santiago de Chile, in the Colonial Period", Early Music, XXXII/3 (agosto), pp. 369-382.

2004c "Las agrupaciones instrumentales en las ciudades e instituciones 'periféricas' de la Colonia: el caso de Santiago de Chile”, en Víctor Rondón (editor). Música colonial iberoamericana: interpretaciones en torno a la práctica de ejecución y ejecución de la práctica. Actas del V Encuentro Simposio Internacional de Musicología "Misiones de Chiquitos”. Santa Cruz de la Sierra, Bolivia: Fondo Editorial Asociación Pro Arte y Cultura [APAC], pp. 109-136.

2005 “A propósito de la recepción de música y músicos extranjeros en el Chile colonial”, Cuadernos de Música Iberoamericana, № 10, pp. 7-34.

2009 "La música en los espacios religiosos", en Marcial Sánchez Gaete (director.). Historia de la Iglesia en Chile. Tomo 1. En los caminos de la conquista espiritual. Santiago: Editorial Universitaria, pp. 287-322. 
2010 “¿Decadencia o progreso? La música del siglo XVIII y el nacionalismo decimonónico”, Latin American Music Review, XXXI/1 (primavera-verano), pp. 1-39.

2011 "Transcending the Walls of the Churches. The Circulation of Music and Musicians of Religious Institutions in Colonial Santiago de Chile", en Geoffrey Baker y Tess Knighton (editores). Music and Urban Society in Colonial Latin America. Cambridge: Cambridge University Press, pp. 171-185.

2012 "De Lima a Santiago de Chile: aportes para una historia de la circulación musical en la América virreinal", en Aurelio Tello (editor). La circulación de música y músicos en la época colonial iberoamericana. Actas del IX Encuentro Científico Simposio Internacional de Musicología. Santa Cruz de la Sierra, Bolivia: Fondo Editorial Asociación Pro Arte y Cultura [APAC], pp. 165-199.

2013 "Trazas y trazos de la circulación musical en el virreinato del Perú: copistas de la catedral de Lima en Santiago de Chile", Anuario Musical, No 68, pp. 133-168.

Vera, Alejandro y Valeska Cabrera

2011 "De la orquesta catedralicia al canto popular: la música religiosa durante el primer centenario de la república”, en Marcial Sánchez Gaete (editor). Historia de la Iglesia en Chile. Volumen 3. Santiago: Editorial Universitaria, pp. 705-777.

Vicent, Alfredo

2002 Fernando Ferandiere (ca. 1740-ca. 1816). Un perfil paradigmático de un músico de su tiempo en España. Madrid: Ediciones Universidad Autónoma de Madrid.

Fuentes manuscritas mencionadas en el texto*

- Archivo Agustino de Santiago, Libro de documentos de La Serena (1595-1794).

- Archivo Agustino de Santiago, "Libro de gastos que hizo y comenzó el M. R. P. Maestro Procurador fr. Pedro Gamboa, desde el día 22 de septiembre de 1780".

- Archivo Agustino de Santiago, "Visita y reforma de esta provincia de Chile", año 1784.

- Archivo de la Catedral de Santiago, Libro general de cuentas (1779).

- Archivo Franciscano de Santiago, Actas del definitorio, vol. 1.

- Archivo Franciscano de Santiago, "Libro de disposición del convento de Santa Rosa Viterbo en el valle de Curimón”.

- Archivo General de Indias, Chile, vol. 65.

- Archivo General de Indias, Chile, vol. 153.

- Archivo General de la Nación del Perú, Real Aduana, C 16.745-820.

- Archivo Histórico del Arzobispado de Santiago, Gobierno, vol. 7.

- Archivo Mercedario de Santiago, Libro 1 de Provincia.

- Archivo Mercedario de Santiago, Libro de administración de la Hacienda del Huaquén (1706-1750).

\footnotetext{
* Se excluyen aquellas listadas en la Tabla 1.
} 
- Archivo Mercedario de Santiago, Libro de gastos del "Convento formado en la villa de Aconcagua”, años 1784-1803.

- Archivo Nacional Histórico, Escribanos de Santiago, vol. 886.

- Archivo Nacional Histórico, Jesuitas de Chile, vol. 24.

\section{Entrevistas}

Entrevista a Francisco Astorga, realizada el 5 de enero de 2015 en la Universidad Metropolitana de Ciencias de la Educación (UMCE), de Santiago. 